\title{
Muscarinic and Nicotinic Acetylcholine Receptor Agonists and Allosteric Modulators for the Treatment of Schizophrenia
}

\author{
Carrie K Jones ${ }^{*, 1,2}$, Nellie Byun ${ }^{1,2,3}$ and Michael Bubser ${ }^{1,2}$ \\ ${ }^{1}$ Vanderbilt Center for Neuroscience Drug Discovery, Vanderbilt University Medical Center, Nashville, TN, USA; ${ }^{2}$ Department \\ of Pharmacology, Vanderbilt University Medical Center, Nashville, TN, USA; ${ }^{3}$ Institute of Imaging Science, Vanderbilt \\ University Medical Center, Nashville, TN, USA
}

Muscarinic and nicotinic acetylcholine (ACh) receptors (mAChRs and nAChRs) are emerging as important targets for the development of novel treatments for the symptoms associated with schizophrenia. Preclinical and early proof-of-concept clinical studies have provided strong evidence that activators of specific mAChR $\left(M_{1}\right.$ and $\left.M_{4}\right)$ and $n A C h R\left(\alpha_{7}\right.$ and $\left.\alpha_{2} \beta_{4}\right)$ subtypes are effective in animal models of antipsychotic-like activity and/or cognitive enhancement, and in the treatment of positive and cognitive symptoms in patients with schizophrenia. While early attempts to develop selective mAChR and nAChR agonists provided important preliminary findings, these compounds have ultimately failed in clinical development due to a lack of true subtype selectivity and subsequent dose-limiting adverse effects. In recent years, there have been major advances in the discovery of highly selective activators for the different mAChR and nAChR subtypes with suitable properties for optimization as potential candidates for clinical trials. One novel strategy has been to identify ligands that activate a specific receptor subtype through actions at sites that are distinct from the highly conserved ACh-binding site, termed allosteric sites. These allosteric activators, both allosteric agonists and positive allosteric modulators, of mAChR and nAChR subtypes demonstrate unique mechanisms of action and high selectivity in vivo, and may provide innovative treatment strategies for schizophrenia.

Neuropsychopharmacology Reviews (2012) 37, 16-42; doi: 10.1038/npp.20I I.199; published online 28 September 20II

Keywords: acetylcholine; schizophrenia and antipsychotics; drug discovery and drug development; schizophrenia

\section{INTRODUCTION}

Schizophrenia is a complex psychiatric illness that affects approximately $1 \%$ of the population worldwide and is characterized by three broad clusters of symptoms that result in lifelong disability. These symptom domains include positive symptoms, such as delusions, thought disorders, and hallucinations; negative symptoms, including anhedonia, blunted affect, and social withdrawal; and cognitive impairments in sensory information processing, attention, working memory, and executive functions (American Psychiatric Association, 2000; Nuechterlein et al, 2004). Clinically available typical (eg, haloperidol) and atypical (eg, clozapine, risperidone) antipsychotic medications provide relief for the positive symptoms, but have little or no effect on the

${ }^{*}$ Correspondence: Dr CK Jones, Department of Pharmacology, Vanderbilt University Medical Center, 2220 Pierce Ave., 418 PRB (6600), Nashville, TN 37232, USA, Tel: +1615343 4337, Fax: + 1615343 3088,

E-mail: carrie.jones@vanderbilt.edu

Received 6 May 2011; revised 6 August 2011; accepted 6 August 2011 negative symptoms or cognitive impairments (Keefe et al, 2007; Swartz et al, 2008). Moreover, poor social and occupational outcomes in individuals with schizophrenia are directly linked with the impairments in normal cognitive function (Green et al, 2004). Effective treatment for schizophrenia is further complicated by marked heterogeneity in the onset of treatment response, with subpopulations of schizophrenic patients showing either delayed onsets of antipsychotic drug action (Kaplan et al, 1990; Garver et al, 1991; McDermott et al, 1991) or rapid responses within hours to days of initiating treatment (Agid et al, 2003, 2008; Kapur et al, 2005; Leucht et al, 2005; Raedler et al, 2007). Other limitations for successful treatment of this disorder include partial responsiveness or treatment resistance to currently available antipsychotic medications (Lieberman et al, 2003) and adverse drug effects, including extrapyramidal motor side effects, metabolic syndrome, and agranulocytosis (Gerlach et al, 1975; Idänpään-Heikkilä et al, 1975; Parsons et al, 2009). While the etiology of schizophrenia is unknown, imbalances in 
several neurotransmitter systems have been implicated in the pathophysiology of this illness, including structural and functional abnormalities in the dopaminergic, glutamatergic, $\gamma$-amino butyric acid (GABA)ergic, and cholinergic systems (Carlsson, 1977; Jentsch and Roth, 1999; Guan et al, 1999; Krystal et al, 2002; Lewis and Moghaddam, 2006; Severance and Yolken, 2008; Scarr et al, 2009; Howes and Kapur, 2009; Beneyto and Lewis, 2011). Taken together, there remains a tremendous unmet need to develop novel therapies to more effectively and safely address the complex symptoms associated with schizophrenia.

The coordination of different cognitive and affective functions requires proper signaling through both muscarinic and nicotinic acetylcholine $(\mathrm{ACh})$ receptors (mAChRs and nAChRs) and disruptions in mAChR and nAChR signaling have been implicated in the symptoms observed in schizophrenic patients (Guan et al, 1999; Severance and Yolken, 2008; Scarr et al, 2009). For example, mAChR and nAChR antagonists, such as scopolamine and mecamylamine, have shown potent amnesiac properties in animals and humans (Domer and Schuller, 1960; Pazzagli and Pepeu, 1965; Rusted and Warburton, 1988; Decker and Majchrzak, 1992; Newhouse et al, 1992, 1994; Terry et al, 1996), whereas mAChR and nAChR agonists and acetylcholinesterase inhibitors (AChEIs) have augmented normal cognition and/or ameliorated impairments induced by lesions of cholinergic circuitry or antagonism of cholinergic receptors (Aigner and Mishkin, 1986; Elrod et al, 1988; Rupniak et al, 1989; Matsuoka et al, 1991; Levin et al, 1998, 2006; Newhouse et al, 2004; Sarter et al, 2009). Furthermore, $\mathrm{mAChR}$ and $\mathrm{nAChR}$ antagonists have exacerbated existing positive and cognitive symptoms in schizophrenic patients and/or induced psychosis in normal human volunteers (Harington and Kincaid-Smith, 1958; Osterholm and Camoriano, 1982; Hamborg-Petersen et al, 1984; Tandon et al, 1991), whereas $\mathrm{mAChR}$ and $\mathrm{nAChR}$ agonists and AChEIs have improved certain aspects of the positive and/or negative symptoms, and attentional and memoryrelated deficits (Janowsky et al, 1973; Smith et al, 2006; Harris et al, 2004; Edelstein et al, 1981; Kirrane et al, 2001; Shekhar et al, 2008). Overall, these preclinical and clinical findings support the hypothesis that imbalances in $\mathrm{mAChR}$ and/or nAChR signaling may underlie the symptoms associated with schizophrenia.

Unfortunately, all cholinergic ligands used in early preclinical and clinical studies, including AChEIs (eg, Forette et al, 1999; Feldman et al, 2007), mAChR agonists (Bodick et al, 1997a,b; Shekhar et al, 2008), and nAChR agonists (Ingram et al, 2005), lacked true receptor subtype selectivity, resulting in numerous dose-limiting adverse effects and failure in clinical development (Bruno et al, 1986; Bodick et al, 1997a, b; Shekhar et al, 2008). For several decades, the lack of subtype-selective ligands for the mAChRs and nAChRs has also prevented a more comprehensive understanding of the fundamental roles of these different receptor subtypes in the central nervous system and in the clinical efficacy observed with AChEIs and non-selective mAChR and nAChR agonists. The interpretation of the effects of non-selective mAChR and nAChR agonists and antagonists in animals and clinical populations is further complicated by the fact that these ligands activate or antagonize both pre- and postsynaptically expressed receptor subtypes. For example, in contrast to the action of the $\mathrm{mAChR}$ antagonist scopolamine on postsynaptic mAChRs, antagonism of presynaptic $\mathrm{mAChRs}$ results in enhanced release of $\mathrm{ACh}$ and subsequent activation of other mAChRs and nAChRs (Bymaster et al, 1993; Quirion et al, 1994; Carey et al, 2001). In addition, recent studies have indicated that there is a critical balance in cholinergic neurotransmission required for normal cognitive and motivational functions that appears to be both brain region- and task-specific (Hasselmo and Sarter, 2010). These findings suggest that tonic enhancement of cholinergic neurotransmission by a mAChR or nAChR agonist may not appropriately normalize cholinergic neurotransmission for the improvement of different cognitive and affective disturbances in schizophrenic patients. However, the state of cholinergic signaling in different brain regions and during different tasks remains unknown in schizophrenia. Potential evidence for regional alterations in cholinergic signaling has been demonstrated in reductions of choline acetyltransferase (ChAT) activity, the catalytic enzyme involved in the synthesis of $\mathrm{ACh}$, in the nucleus accumbens and pontine tegmentum of postmortem brain tissue from schizophrenic patients (Bird et al, 1977; Karson et al, 1993). Moreover, reductions in cortical and pontine tegmentum ChAT activity have been directly correlated with decreased cognitive performance in schizophrenic patients (Karson et al, 1996; Powchik et al, 1998). Using magnetic resonance spectroscopy, elevated levels of free choline and phosphocholines, precursors of ACh and membrane phospholipids, respectively, have also been detected in thalamic, anterior cingulate, and caudate brain regions of antipsychotic-naive individuals with schizophrenia (Bustillo et al, 2002). These alterations are constistent with abnormalities in phospholipid membrane synthesis and integrity, but may also reflect impaired ChAT function. By contrast, other studies have found no changes or regional elevations in ChAT activity, indicating the potential for variability and/or artifacts with the use of postmortem brain tissues (eg, differences in tissue quality, postmortem interval, patient medication history, appropriate age-matched controls, and/ or small cohort sizes) (Domino et al, 1973; McGeer and McGeer, 1977). Limitations with these early pharmacological and postmortem studies further support the need to develop subtype-selective $\mathrm{mAChR}$ and $\mathrm{nAChR}$ ligands. However, the high conservation of the ACh-binding site across the different $\mathrm{mAChR}$ or $\mathrm{nAChR}$ subtypes has presented a major obstacle to the development of highly selective ACh orthosteric-site ligands.

Over the last decade, a novel approach has been undertaken in the discovery of mAChR and nAChR ligands that activate a particular receptor subtype by actions at sites that are topographically distinct and less highly conserved than 
the orthosteric binding site of $\mathrm{ACh}$, termed allosteric sites. The development of allosteric activators is already a well validated approach with benzodiazepines, which are allosteric activators of $\mathrm{GABA}_{\mathrm{A}}$ receptors and provide a safe, effective treatment approach for anxiety disorders without inducing adverse effects of direct-acting $\mathrm{GABA}_{\mathrm{A}}$ receptor agonists (Ehlert et al, 1983). Allosteric activators of mAChRs and nAChRs possess high subtype selectivity and can show different modes of action. Allosteric agonists can activate the receptor subtype directly and do not require the presence of ACh. Positive allosteric modulators (PAMs), on the other hand, do not directly activate the receptor, but bind to an allosteric site distinct from the ACh-binding site and potentiate the effects of endogenous ACh. One potential advantage of the use of mAChR and nAChR PAMs is that these ligands have no intrinsic activity and can only exert their effects in the presence of ACh at a given synapse, thereby maintaining some level of activity dependence of endogenous receptor activation. In the case of nAChRs, another approach has been the development of selective partial nAChR agonists, most notably for the $\alpha_{7} \mathrm{nAChR}$, which provide receptor activation with less desensitization. To date, these novel agonists and allosteric activators of the different $\mathrm{mAChR}$ and $\mathrm{nAChR}$ subtypes have shown robust efficacy in preclinical models of antipsychotic-like activity and/or enhancement of cognitive function, and possess suitable physiochemical properties for optimization as potential clinical candidates. In this review, we will provide a brief overview of cholinergic neurotransmission, circuitry, and $\mathrm{mAChR}$ and $\mathrm{nAChR}$ structure and function. We will next describe the evidence for the roles of the muscarinic and nicotinic cholinergic systems in the pathophysiology of schizophrenia. We will then review the preclinical and clinical breakthroughs in the development of highly subtype-selective allosteric agonists and PAMs for the mAChRs, most notably $\mathrm{M}_{1}$ and $\mathrm{M}_{4}$, and the partial agonists and PAMs for the $\alpha_{7}$ and $\alpha_{4} \beta_{2}$ nAChRs, and their potential advantages and limitations for the treatment of schizophrenia.

\section{ACh AND CHOLINERGIC TRANSMISSION}

Central cholinergic transmission is coordinated through projection neurons and interneurons. Cholinergic projection neurons are organized into relatively discrete cell groups, Ch1-Ch6, with distinct projection patterns. The basal forebrain cholinergic projection neurons (Ch1-Ch4) in the medial septum, diagonal band of Broca, and the nucleus basalis of Meynert are the major source of ACh to the cortical and hippocampal regions (Mesulam et al, 1983). The cholinergic projection neurons with the cell bodies in the pedunculopontine tegmantal nucleus (Ch5) and the laterodorsal tegmental nucleus (Ch6) project to the thalamus, pontine reticular formation, and the dopamine (DA) neurons in the ventral tegmental area (VTA) and the substantia nigra (SN) (Satoh and Fibiger, 1986). In the caudate-putamen and nucleus accumbens, large cholinergic interneurons are the only source of Ach (Kimura et al, 1980; Bolam et al, 1984; Phelps et al, 1985). Thus, the central cholinergic system is strategically positioned to modulate brain function at sites thought to be impacted by schizophrenia, especially through key functional interactions with dopaminergic and glutamatergic systems.

ACh modulates a host of physiological processes in the central and peripheral nervous systems. Centrally, ACh regulates motor function, sensory perception, cognitive processing, arousal, sleep/wake cycles, and nociception, while in the periphery it controls heart rate, gastrointestinal tract motility, and smooth muscle activity (Abrams et al, 2006). ACh mediates its effects through activation of two functionally and structurally distinct families of cell-surface receptors, the mAChRs and nAChRs. A schematic representation of a hypothetical cholinergic synapse illustrating the general synaptic localization and the function of the mAChRs and nAChRs is shown in Figure 1. The nAChRs, members of the ligand-gated ion channel superfamily that includes $\mathrm{GABA}_{\mathrm{A}}$ and $\mathrm{GABA}_{\mathrm{C}}$ receptors, are divided into muscle nAChRs at the skeletal neuromuscular junction and neuronal nAChRs, which mediate fast synaptic neurotransmission throughout the nervous system (Harvey and Dryden, 1974; Mulle et al, 1991). The mAChRs are members of the Family-A G-protein-coupled receptors (GPCRs) and provide slower and more sustained synaptic responses through second messenger systems (Dutar and Nicoll, 1988). Both muscarinic and nicotinic receptors exist in various subtypes offering numerous ways to pharmacologically alter cholinergic transmission.

\section{Muscarinic Receptor Subtypes}

Structure of mAChRs. To date, five molecularly distinct mammalian subtypes of $\mathrm{mAChRs}, \mathrm{M}_{1}-\mathrm{M}_{5}$, have been cloned (Bonner et al, 1987, 1988; Liao et al, 1989). Each of the five $\mathrm{mAChR}$ subtypes is a seven-transmembrane (TM) protein that can be further divided into two major functional classes based on G-protein coupling (see Figure 2). The $M_{1}, M_{3}$, and $\mathrm{M}_{5} \mathrm{mAChRs}$ selectively couple to the Gq/G11-type G-proteins, which leads to the generation of inositol-1,4,5trisphosphate and 1,2-diacylglycerol through activation of phosphoinositide-specific phospholipase- $\mathrm{C} \beta$, and subsequent increases of intracellular calcium levels (Felder, 1995; Espada et al, 2009). The $\mathrm{M}_{2}$ and $\mathrm{M}_{4}$ mAChRs preferentially activate Gi/Go-type G-proteins, resulting in the inhibition of adenylyl cyclase and prolongation of the opening of potassium, nonselective cation, and transient receptor potential channels (Felder, 1995; Migeon et al, 1995). All mAChR subtypes show a high homology sequence for the orthosteric AChbinding site, which is thought to account for the past difficulties in developing subtype-selective ligands for muscarinic receptors.

Distribution and function of mAChRs. Neuroanatomical studies using subtype-specific antibodies for the different mAChRs have established distinct patterns of expression for 


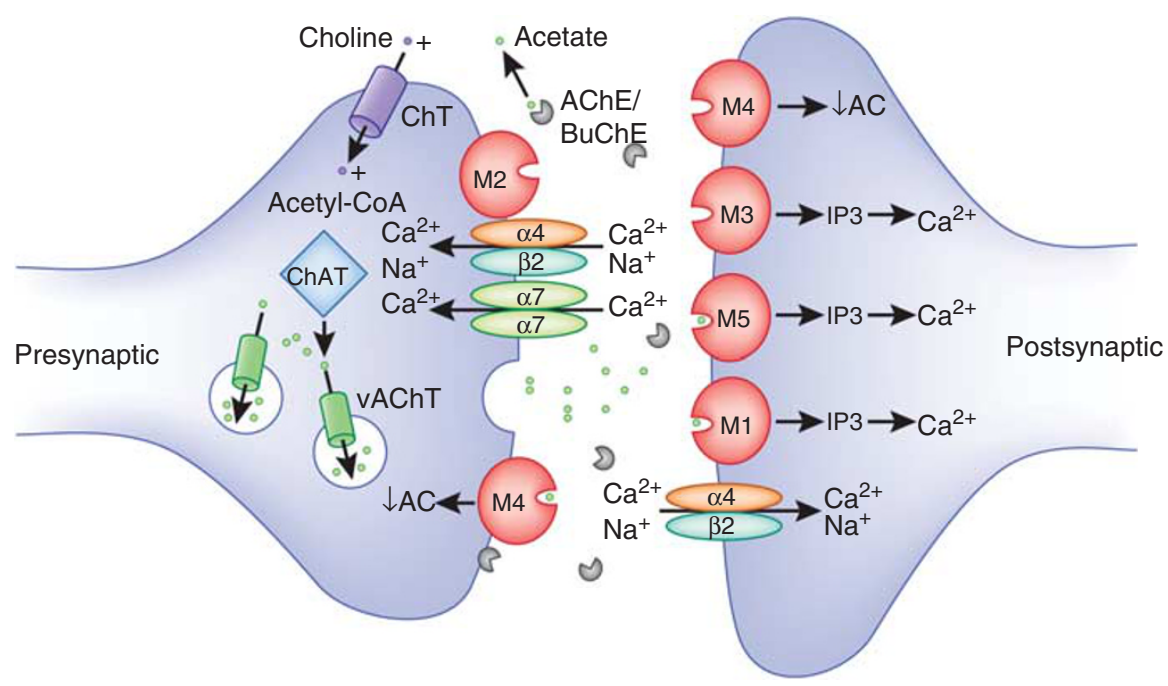

Figure 1. Schematic representation of a hypothetical cholinergic synapse illustrating general synaptic localization and function of cholinergic receptors relevant to schizophrenia. mAChR subtypes have diverse synaptic localization patterns and function pre- and postsynaptically to modulate neurotransmitter release and postsynaptic excitability, respectively. For instance, the $M_{2}$ and $M_{4} m A C h R s$ serve as autoreceptors on cholinergic terminals to suppress ACh release and inhibit cholinergic neurotransmission at select synapses in the central nervous system (left neuron). The mAChRs located on non-cholinergic neurons act as heteroceptors controlling the release of other neurotransmitters, such as DA (not shown). $M_{1}, M_{3}, M_{5}$, but also $M_{4}$ mAChRs that are located postsynaptically facilitate slow cholinergic synaptic neurotransmission relative to nAChR subtypes. The $\alpha_{7}$ and $\alpha_{4} \beta_{2}$ nAChR subtypes mediate fast synaptic transmission and also use-dependent changes required for neuronal plasticity. These nAChR subtypes can have both pre- and postsynaptic localization. The endogenous ligand of these cholinergic receptors, ACh, is synthesized in cholinergic neurons (left neuron) by the enzyme ChAT through the transfer of acetyl-CoA onto choline. Choline uptake is mediated by presynaptic high-affinity choline transporters (ChT). After synthesis, ACh is packaged into synaptic vesicles by the vesicular ACh transporter (vAChT). After neuronal activation-mediated release into the synaptic cleft, ACh can bind to pre- and postsynaptic receptors, or it can be inactivated through hydrolysis by the AChE enzymes, a process that can be inhibited by different substances (eg, organophosphates, AChE inhibitors) to increase synaptic ACh levels. Once ACh is hydrolyzed, choline is transported through the ChTs into the presynaptic terminal, where it is again synthesized into ACh.

the different $\mathrm{mAChR}$ subtypes within key forebrain and limbic structures (Levey et al, 1991, 1994, 1995a, b). More recently, the development and characterization of knockout (KO) mice for each of the mAChR subtypes have provided a clearer understanding of the central and peripheral functions of each subtype (see Wess et al, 2007).

As the predominant subtype in the central nervous system, the $M_{1} m A C h R$ is expressed in the striatum, throughout all layers of the cortex, and postsynaptically on the cell bodies and dendrites of hippocampal pyramidal neurons and granule cells (Levey et al, 1991, 1995b; Marino et al, 1998; Rouse et al, 1998, 1999). One of the most important effects of $M_{1} m A C h R$ activation in the hippocampus and other forebrain regions is the potentiation of currents through the $N$-methylD-aspartate receptor (NMDAR) of the glutamatergic system (Marino et al, 1998). Owing to the major contribution of NMDAR signaling to the regulation of cognitive function and neural circuits thought to be disrupted in schizophrenia (Tsai and Coyle, 2002; Marino et al, 1998), ligands that selectively activate $\mathrm{M}_{1} \mathrm{mAChRs}$ are postulated to alleviate some of the psychotic and cognitive deficits observed in schizophrenia through enhancement of NMDAR neurotransmission. In addition, recent studies by Shirey et al (2009) have shown that activation of $\mathrm{M}_{1}$ mAChRs markedly increases the synaptic excitation of pyramidal cells in the medial prefrontal cortex (mPFC) and enhances mPFC-mediated cognitive functions, including performance in attentional set shift tasks. By contrast, $\mathrm{M}_{1}-\mathrm{KO}$ mice showed specific deficits in tasks requiring $\mathrm{mPFC}$ function (Anagnostaras et al, 2003). Other changes observed in $\mathrm{M}_{1}-\mathrm{KO}$ mice, particularly increased spontaneous locomotor activity and enhanced amphetamine-induced hyperactivity coupled with a twofold increase in extracellular striatal DA (Gerber et al, 2001; Miyakawa et al, 2001), indicate a role for the $\mathrm{M}_{1} \mathrm{mAChRs}$ in the regulation of the dopaminergic system.

The $\mathrm{M}_{2}$ mAChRs are expressed presynaptically on cholinergic terminals throughout the brain, particularly in the cortex, basal forebrain, hippocampus, and striatum, and function as autoreceptors to inhibit ACh release (Rouse et al, 2000; Zhang et al, 2002; Tzavara et al, 2003), suggesting that selective $\mathrm{M}_{2} \mathrm{mAChR}$ antagonists may be beneficial for cognition. $\mathrm{M}_{2} \mathrm{mAChRs}$ are also localized on the axon terminals of non-cholinergic neurons and serve as heteroceptors involved in the presynaptic regulation of release of other neurotransmitters (Rouse et al, 2000). The deficits of $\mathrm{M}_{2}-\mathrm{KO}$ mice in behavioral flexibility, working memory, passive avoidance learning, and hippocampal short- and long-term potentiation (LTP) (Gomeza et al, 1999b; Tzavara et al, 2003; Seeger et al, 2004) are consistent with the interpretation that blockade of all $\mathrm{M}_{2} \mathrm{mAChRs}$ on cholinergic and non-cholinergic terminals may actually have detrimental effects on cognition. To date, it is unclear whether $\mathrm{M}_{2} \mathrm{mAChR}$ antagonists will actually be beneficial 


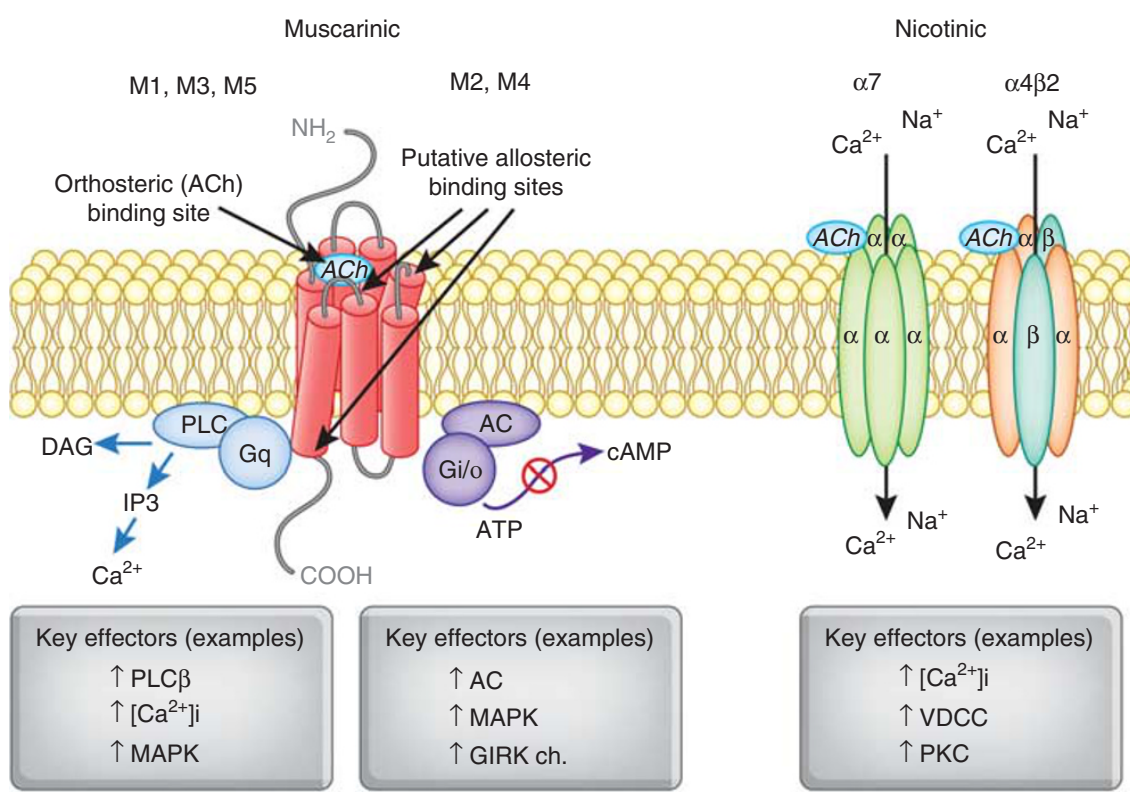

Figure 2. The structure and signaling pathways of $m A C h R s$ and $n A C h R s$. Each mAChR subtype is a seven-transmembrane protein, which belongs to two major functional classes based on G-protein coupling. The $M_{1}, M_{3}$, and $M_{5}$ mAChRs selectively couple to the Gq/G11-type G-proteins resulting in the generation of inositol-1,4,5-trisphosphate (IP3) and 1,2-diacylglycerol (DAG) through activation of the phosphoinositide-specific phospholipase-C $\beta$ leading to increased intracellular calcium levels. The $\mathrm{M}_{2}$ and $\mathrm{M}_{4} \mathrm{mAChRs}$ preferentially activate Gi/Go-type G-proteins, thereby inhibiting adenylate cyclase, reducing intracellular concentration of CAMP, and prolonging potassium channel opening. All mAChR subtypes show a high sequence homology across species, particularly in the orthosteric ACh-binding sites. Neuronal nAChRs are pentameric ligand-gated ion channels. The most abundant neuronal subunits are $\alpha_{4}, \beta_{2}$, and $\alpha_{7}$, with the heteromeric $\alpha_{4} \beta_{2}$ receptor subtype in highest abundance. The heteromeric $\alpha_{4} \beta_{2}$ receptor subtype can exist in two different forms: $(\alpha 4)_{2}(\beta 2)_{3}$ receptors show low $\mathrm{Ca}^{2+}$ permeability and high affinity to ACh and nicotine, whereas $(\alpha 4)_{3}(\beta 2)_{2}$ receptors have high $\mathrm{Ca}^{2+}$ permeability. By contrast, the $\alpha_{7} \mathrm{nAChR}$ also shows high permeability to $\mathrm{Ca}^{2+}$ relative to the heteromeric $\alpha_{4} \beta_{2} \mathrm{nAChRs}$. The action of $\alpha_{4} \beta_{2}$ nAChRs can enhance intracellular levels of $\mathrm{Ca}^{2+}$ by secondary activation of VOCCs, whereas $\alpha_{7}$ nAChRs preferentially increase Ca ${ }^{2+}$ release from ryanodine-sensitive intercellular stores through CICR. The capacity of these different nAChR subtypes to couple to VOCC or CICR mechanisms results in distinct patterns of $\mathrm{Ca}^{2+}$ signaling that can provide a broader control of synaptic plasticity and neurotransmitter release, as well as gene transcription.

for the cognitive deficits and other symptoms observed in schizophrenia.

Compared with the other mAChR subtypes, relatively little is known about the role of the neuronal $\mathrm{M}_{3} \mathrm{mAChRs}$, which are expressed at low levels throughout the central nervous system. $\mathrm{M}_{3}-\mathrm{KO}$ mice are lean and hypophagic, with decreased serum leptin levels, a phenotype that appeared to be hypothalamus-driven rather than from decreased salivary flow or gastrointestinal motility (Yamada et al, 2001b). More recently, $\mathrm{M}_{3}$-deficient mice were shown to have severe deficits in hippocampus-mediated contextual fear conditioning, suggesting that selective $\mathrm{M}_{3} \mathrm{mAChR}$ activators may be beneficial for cognition (Poulin et al, 2010).

The $\mathrm{M}_{4} \mathrm{mAChRs}$ are located across many brain regions, including the cortex and hippocampus, but are most prominent in the striatum (Levey et al, 1991; Hersch et al, 1994; Rouse et al, 1999) where they are enriched in cholinergic interneurons and striatal projection neurons, particularly those projecting directly to the SN (Ince et al, 1997). The $\mathrm{M}_{4}$ mAChRs can function as autoreceptors in the striatum and midbrain (Zhang et al, 2002; Tzavara et al, 2004), and as postsynaptic modulatory receptors in the striatum, neocortex, and hippocampus (Levey et al, 1991; Zang and Creese, 1997). $\mathrm{M}_{4}$-KO mice showed increased locomotor activity, enhanced DA D1 receptor-mediated effects (Gomeza et al, 1999a), and increased basal and psychostimulant-induced DA levels in the nucleus accumbens (Tzavara et al, 2004), which are recapitulated in mice with targeted $\mathrm{KO}$ of $\mathrm{M}_{4} \mathrm{mAChRs}$ in neurons expressing DA D1 receptors (Jeon et al, 2010). Taken together, this hyper-dopaminergic phenotype suggests that facilitation of $\mathrm{M}_{4}$ mAChR function may be beneficial for the treatment of schizophrenia. For example, stimulation of $\mathrm{M}_{4}$ autoreceptors, located on the terminals of cholinergic neurons in the caudal midbrain, is predicted to decrease the activity of dopaminergic VTA neurons, leading to a reduction of nucleus accumbal DA release.

By contrast, the $M_{5} m A C h R s$ have only been found postsynaptically on the dopaminergic neurons in the VTA and SN pars compacta, the two brain regions that provide dopaminergic innervation to the dorsal striatum, nucleus accumbens, and mPFC (Vilaró et al, 1990; Weiner et al, 1990). $\mathrm{M}_{5}$-KO mice showed deficits of pre-pulse inhibition (PPI) of the acoustic startle reflex, indicating abnormal sensorimotor gating (Thomsen et al, 2007) and reduced sensitivity to the locomotor and/or rewarding effects of cocaine (Fink-Jensen et al, 2003; Thomsen et al, 2005) and opiates (Basile et al, 2002; 
Yamada et al, 2003; Steidl and Yeomans, 2009), two strong activators of mesolimbic DA signaling. These findings suggest that selective $M_{5} \mathrm{mAChR}$ antagonists may be useful for controlling the hyperactive mesolimbic dopaminergic circuitry that is reported in schizophrenia. Non-neuronal $\mathrm{M}_{5} \mathrm{mAChRs}$ are localized to the cerebrovasculature and control cerebral vasodilation and blood flow (Yamada et al, 2001a; Araya et al, 2006). The neuronal atrophy and impairments in novel object recognition observed in $\mathrm{M}_{5}$-KO mice (Araya et al, 2006) may be due to dysfunction of the cerebrovasculature and therefore of non-neuronal origin.

\section{Nicotinic Receptor Subtypes}

Structure of $n A C h R s$. Neuronal nAChRs are pentameric ligand-gated ion channels (see Figure 2). To date, molecular cloning has identified nine $\alpha\left(\alpha_{2}-\alpha_{10}\right)$ and three $\beta$-subunits $\left(\beta_{2}-\beta_{4}\right)$ (Conti-Tronconi et al, 1982). Homomeric nAChRs are composed only of $\alpha$-subunits $\left(\alpha_{7}-\alpha_{9}\right.$ subtype), whereas heteromeric nAChRs have different combinations of $\alpha$ and $\beta$-subunits (eg, the $\alpha_{4} \beta_{2}$ subtype). The most abundant neuronal subunits are $\alpha_{4}, \beta_{2}$, and $\alpha_{7}$, with the heteromeric $\alpha_{4} \beta_{2}$ receptor subtype comprising over $90 \%$ of all neuronal nAChRs (Corriveau and Berg, 1993; Perry et al, 2002). The $\alpha_{4} \beta_{2} \mathrm{nAChR}$ is composed of $\alpha_{4}$ and $\beta_{2}$ subunits that can be expressed in two different stoichiometries, the $\left(\alpha_{4}\right)_{2}\left(\beta_{2}\right)_{3}$ and $\left(\alpha_{4}\right)_{3}\left(\beta_{2}\right)_{2}$ receptor subtypes (Tapia et al, 2007). The $\left(\alpha_{4}\right)_{2}\left(\beta_{2}\right)_{3}$ receptors show low $\mathrm{Ca}^{2+}$ permeability and high affinity to $\mathrm{ACh}$ and nicotine, whereas the $\left(\alpha_{4}\right)_{3}\left(\beta_{2}\right)_{2}$ receptors have high $\mathrm{Ca}^{2+}$ permeability with low sensitivity to nicotine (Anderson et al, 2009; Carbone et al, 2009). In contrast to the $\alpha_{4} \beta_{2}$ nAChR subtype, the $\alpha_{7}$ nAChR shows relatively low $\mathrm{ACh}$ affinity and rapid desensitization kinetics in the presence of $100 \mu \mathrm{M}$ ACh or higher (Fenster et al, 1997). The $\alpha_{7} \mathrm{nAChR}$ also shows high permeability to $\mathrm{Ca}^{2+}$ relative to the heteromeric $\alpha_{4} \beta_{2}$ nAChRs (Seguela et al, 1993). Whereas $\alpha_{4} \beta_{2}$ nAChRs can further augment the intracellular levels of $\mathrm{Ca}^{2+}$ by secondary activation of voltage-operated calcium channels (VOCCs), $\alpha_{7}$ nAChRs preferentially mobilize $\mathrm{Ca}^{2+}$ release from ryanodine-sensitive intracellular stores through a $\mathrm{Ca}^{2+}$-induced $\mathrm{Ca}^{2+}$ release (CICR) (Dajas-Bailador et al, 2002). The capacity of these different nAChR subtypes to couple to VOCC or CICR mechanisms results in distinct patterns of $\mathrm{Ca}^{2+}$ signaling that may deliver a broader control of synaptic signaling and neurotransmitter release.

There are four traditional conformation states of activation for all nAChRs: resting (closed channel with an unoccupied agonist-binding site), active (open channel), desensitized (closed channel with high-affinity agonist binding), and an inactive state that is a more prolonged desensitized state (Changeux et al, 1984). With acute exposure to high concentrations of $\mathrm{ACh}$ or non-selective nAChR agonists such as nicotine, the equilibrium between these conformation states shifts to an active state, allowing signal transduction followed by subsequent desensitization of the receptor. However, under sustained exposure to low concentrations of agonists, the desensitized conformational state of the receptor can be stabilized and become refractory to agonist activation. The ACh-binding site for activation of nAChRs is located at the interface between the $\alpha$-subunit and an adjacent subunit (Blount and Merlie, 1989). The $\alpha_{4} \beta_{2}$ nAChR contains two identical ACh-binding sites, whereas the homomeric $\alpha_{7} \mathrm{nAChR}$ contains up to five possible AChbinding sites (Palma et al, 1996). Although the $\alpha_{7} \mathrm{nAChR}$ shows lower sensitivity to $\mathrm{ACh}$ activation and rapid desensitization, it has been speculated that the five AChbinding sites provide a more versatile range of sensitivity and signaling than other $\mathrm{nAChR}$ subtypes.

Distribution and function of $\alpha_{7}$ and $\alpha_{4} \beta_{2} n A C h R s$. The $\alpha_{7}$ and $\alpha_{4} \beta_{2}$ nAChR subtypes are expressed on postsynaptic membranes (Schoepfer et al, 1990; Gotti and Clementi, 2004; Perry et al, 2002) or presynaptically to regulate the release of $\mathrm{ACh}$ and other neurotransmitters (Wonnacott, 1997; Li et al, 1998; Sher et al, 2004) in key corticolimbic circuits shown to be disrupted in schizophrenia. In the hippocampus, the nAChRs are expressed predominantly on GABAergic interneurons, with moderate expression on pyramidal neurons (Fabian-Fine et al, 2001; Ji et al, 2001). The majority of these neurons express the $\alpha_{7} \mathrm{nAChR}$ subtype, whereas a fraction of interneurons are also mecamylamine-sensitive indicating the presence of non- $\alpha_{7}$ nAChRs (Ji and Dani, 2000; McQuiston and Madison, 1999). The rapid desensitization of the $\alpha_{7} \mathrm{nAChR}$ subtype provides a critical feedback mechanism for cholinergic signaling, especially for the autoregulation of neurotransmission at cholinergic synapses where fast desensitization can avoid the potential for uncontrolled increases in response. While extensive behavioral characterization of $\alpha_{7}-\mathrm{KO}$ mice demonstrated that the $\alpha_{7}$-subunit is not required for a number of normal behavioral responses (Paylor et al, 1998), these mutant mice did lack rapidly desensitizing nicotinic currents in the hippocampal neurons, suggesting the involvement of $\alpha_{7}$-containing nAChRs in hippocampus-mediated synaptic plasticity (Orr-Urtreger et al, 1997; Ji et al, 2001). In addition, the nicotine activation of presynaptic $\alpha_{7}$ nAChRs induces long-term enhancement of glutamatergic transmission in the VTA (Mansvelder and McGehee, 2000), whereas stimulation of non- $\alpha_{7}$ nAChR postsynaptic receptors can enhance GABAergic signaling (Mansvelder et al, 2002). For example, the $\alpha_{4} \beta_{2}$ nAChRs localized on somatodendritic regions of interneurons facilitate inhibitory GABA signaling (see Albuquerque et al, 2009). Several studies have also reported anatomical and pharmacological evidence for functional presynaptic $\alpha_{4} \beta_{2}$ nAChRs that modulate DA release from nigrostriatal terminals (Soliakov et al, 1995; Soliakov and Wonnacott, 1996; Luo et al, 1998; Wonnacott et al, 2000) and loss of nicotine-induced stimulation of nucleus accumbal DA release in $\beta_{2} \mathrm{KO}$ mice. Interestingly, the $\beta_{2}$-subunitcontaining nAChRs may provide an important role for neuron survival and maintenance of normal cognitive 
functions during aging as aged $\beta_{2}-\mathrm{KO}$ mice at $22-24$ months show disruptions in spatial learning tasks, cortical and hippocampal neuronal atrophy, gliosis, and an increase of serum corticosterone levels (Zoli et al, 1999). In $\alpha_{4}-\mathrm{KO}$ mice, high-affinity nicotine-induced physiological responses were absent in the thalamic and raphe magnus neurons, and the antinociceptive effects of nicotine were diminished (Marubio et al, 1999).

\section{ROLE OF MUSCARINIC RECEPTOR SUBTYPES IN SCHIZOPHRENIA}

Multiple lines of evidence suggest that alterations in central muscarinic cholinergic neurotransmission are involved in the underlying pathophysiology of schizophrenia. Early validation came from extensive preclinical and clinical studies with non-selective mAChR ligands. Non-selective mAChR antagonists (eg, scopolamine) robustly impaired multiple cognitive functions, such as sensory information processing, attention, learning, working and short-term memory, and executive tasks, whereas direct- and indirectacting (eg, AChEIs) mAChR agonists enhanced aspects of normal cognition and/or reversed cognitive impairments induced by $\mathrm{mAChR}$ antagonists or cholinergic circuit lesions (Aigner and Mishkin, 1986; Rusted and Warburton, 1988; Rupniak et al, 1989; Matsuoka et al, 1991; Decker and Majchrzak, 1992). Moreover, mAChR antagonists induced psychotic-like symptoms and cognitive impairments in healthy subjects and/or exacerbated existing positive and cognitive symptomatology in schizophrenic patients (Osterholm and Camoriano, 1982; Hamborg-Petersen et al, 1984; Tandon et al, 1991). Non-selective mAChR agonists have been reported, albeit in many cases anecdotally, to provide moderate efficacy for the symptoms in schizophrenic patients (Pfeiffer and Jenny, 1957; Edelstein et al, 1981). Unfortunately, interpretations of these early studies are confounded by the lack of true subtype-selective ligands in vivo. Nevertheless, postmortem, clinical imaging, and genetic approaches have further implicated $\mathrm{mAChR}$ expression and function in the underlying pathophysiology of schizophrenia.

Several postmortem $\left[{ }^{3} \mathrm{H}\right]$ pirenzepine-binding studies have demonstrated decreased levels of $\mathrm{M}_{1} / \mathrm{M}_{4} \mathrm{mAChRs}$ in specific brain regions of schizophrenic patients, including the prefrontal and anterior cingulate cortices, superior temporal gyrus, hippocampus, and dorsal striatum (Dean et al, 1996, 2002; Crook et al, 1999, 2000, 2001; Katerina et al, 2004; Deng and Huang, 2005). These changes in $\mathrm{mAChR}$ expression appear to be specific to schizophrenia, as similar decreases were not observed in patients with bipolar disorder or major depression (Zavitsanou et al, 2004). Others have found decreased levels of $M_{1} m A C h R$ mRNA and/or protein in the superior prefrontal gyrus and dorsolateral PFC in individuals with schizophrenia (Mancama et al, 2003; Dean et al, 2002). In addition, in vivo mAChR occupancy was decreased by $20-33 \%$ in a group of unmedicated schizophrenic patients relative to controls
(Raedler et al, 2003), and although the use of a pan-mAChR SPECT ligand for these studies does not provide information on which mAChR subtype(s) are decreased, the results are consistent with the postmortem studies. Taken together, these anatomical studies suggest that decreases in $\mathrm{mAChR}$ levels may be both region- and subtype-specific in schizophrenic patients. However the interpretation of these findings may be confounded by the lack of subtypeselective radioligands and the possible effects of atypical antipsychotics. Interestingly, a polymorphism of the $\mathrm{M}_{1}$ mAChR gene (CHRM1) was associated with improved performance on the Wisconsin Card Sorting Test in schizophrenic patients (Liao et al, 2003). Other cholinergic receptor genes have also been linked to schizophrenia. For example, the $\mathrm{M}_{5} \mathrm{mAChR}$ (CHRM5) and $\alpha_{7} \mathrm{nAChR}$ (CHRNA7) genes on 15q13 were also found to confer susceptibility to schizophrenia (De Luca et al, 2004).

\section{Breakthrough with the $M_{1} / M_{4} m A C h R$ Agonist Xanomeline}

Over the last two decades, mAChR agonists developed for the cognitive impairment associated with Alzheimer's disease (AD) and other dementias have failed during clinical trials owing to dose-limiting adverse effects from non-selective activation of peripheral mAChR subtypes (Bruno et al, 1986; Bodick et al, 1997a,b). However, in one large multicenter trial on the effects of the $M_{1} / M_{4}$ mAChR agonist xanomeline in $\mathrm{AD}$ patients, significant effects were observed on the behavioral disturbances with a trend toward improvement in cognition (Bodick et al, 1997a, b). In particular, xanomeline produced a robust dosedependent reduction in vocal outbursts, suspiciousness, delusions, agitation, and hallucinations, while improving blunted affect and other AD-related behavioral disturbances that share similarities to those observed in schizophrenia. This surprising finding raised the possibility that xanomeline might provide a novel approach for the treatment of schizophrenia.

In preclinical models predictive of antipsychotic-like activity, xanomeline was shown to produce an efficacy profile similar to atypical antipsychotics like clozapine (Stanhope et al, 2001; Perry et al, 2001; Jones et al, 2005). For example, xanomeline induced Fos expression and increased monoamine turnover in the PFC and nucleus accumbens but not in the dorsal striatum (Perry et al, 2001). After acute and chronic dosing, xanomeline inhibited VTA, but not SN, DA cell firing similar to clozapine (Shannon et al, 2000). In rodent behavioral studies, xanomeline dose dependently inhibited conditioned avoidance responding, amphetamine-induced hyperlocomotion, and apomorphine-induced climbing without induction of catalepsy as seen with the typical antipsychotic haloperidol (Shannon et al, 2000). Moreover, xanomeline dose dependently reversed the apomorphineinduced disruption of PPI, a preclinical model of sensory information processing deficits. Many of the preclinical 
findings with xanomeline were also confirmed in nonhuman primates (Andersen et al, 2003). Based on these preclinical studies, a subsequent 4 -week, double-blind, placebo-controlled outcome trial in subjects with schizophrenia $(n=20)$ was performed to evaluate the potential antipsychotic efficacy of xanomeline (Shekhar et al, 2008). In these studies, xanomeline treatment led to marked improvements in schizophrenic patients as compared with the placebo group, as measured by the Brief Psychiatric Rating Scale (BPRS), Positive and Negative Syndrome Scale (PANSS), and Clinical Global Impression (Shekhar et al, 2008). The response to xanomeline was superior to that previously reported in studies using typical and atypical antipsychotics with a delayed onset of action (Kaplan et al, 1990, Garver et al, 1991; McDermott et al, 1991). In particular, the xanomeline group showed a statistically significant change in BPRS scores after 1 week of treatment, which continually improved throughout the study, as well as statistically significant improvements in total PANSS scores. In a test battery that addressed multiple domains of cognition, including visuospatial learning, verbal learning, attention/vigilance, speed of processing, and working memory, xanomeline significantly improved verbal learning and short-term memory, indicating efficacy in some aspects of cognition (Shekhar et al, 2008). Adverse effects, specifically gastrointestinal, were observed in the xanomeline treatment group. Although these side effects did not lead to any discontinuation, the dose limitations prevented xanomeline from long-term clinical use. These studies, however, provided important clinical validation of the potential of $\mathrm{mAChR}$ agonists as novel therapeutic agents for treatment of psychosis as well as cognitive disturbances in schizophrenia patients. These findings also raised the question of whether activation of $\mathrm{M}_{1}, \mathrm{M}_{4}$, or both receptors is critical for the observed clinical effects.

\section{Allosteric Modulation of Muscarinic Receptors}

$M_{1}$ allosteric modulators. Remarkable progress has been achieved in the discovery of $\mathrm{M}_{1}$ allosteric activators that provide tools to further the understanding of the relative contributions of $M_{1}$ to the preclinical and clinical efficacy of xanomeline (see Table 1). The first generation of $M_{1}$ mAChR allosteric activators includes brucine, a selective, but weak PAM, increasing ACh affinity only two-fold and most notably, AC-42, the first $M_{1}$ compound with demonstrated action through binding at an allosteric site on the $M_{1}$ mAChR. Through a systematic evaluation of chimeric receptors, AC- 42 was shown to activate $M_{1} \mathrm{mAChRs}$ within only the 1 and 7 TM domains, without interactions at other TM domains that contribute to the orthosteric ACh-binding site (Spalding et al, 2002; Langmead et al, 2006). Although these first-generation $M_{1}$ PAMs provided an important demonstration of allosteric activity in recombinant systems, these ligands suffered from unsuitable physiochemical properties to advance into studies in animal models. Interestingly, previous studies have demonstrated that

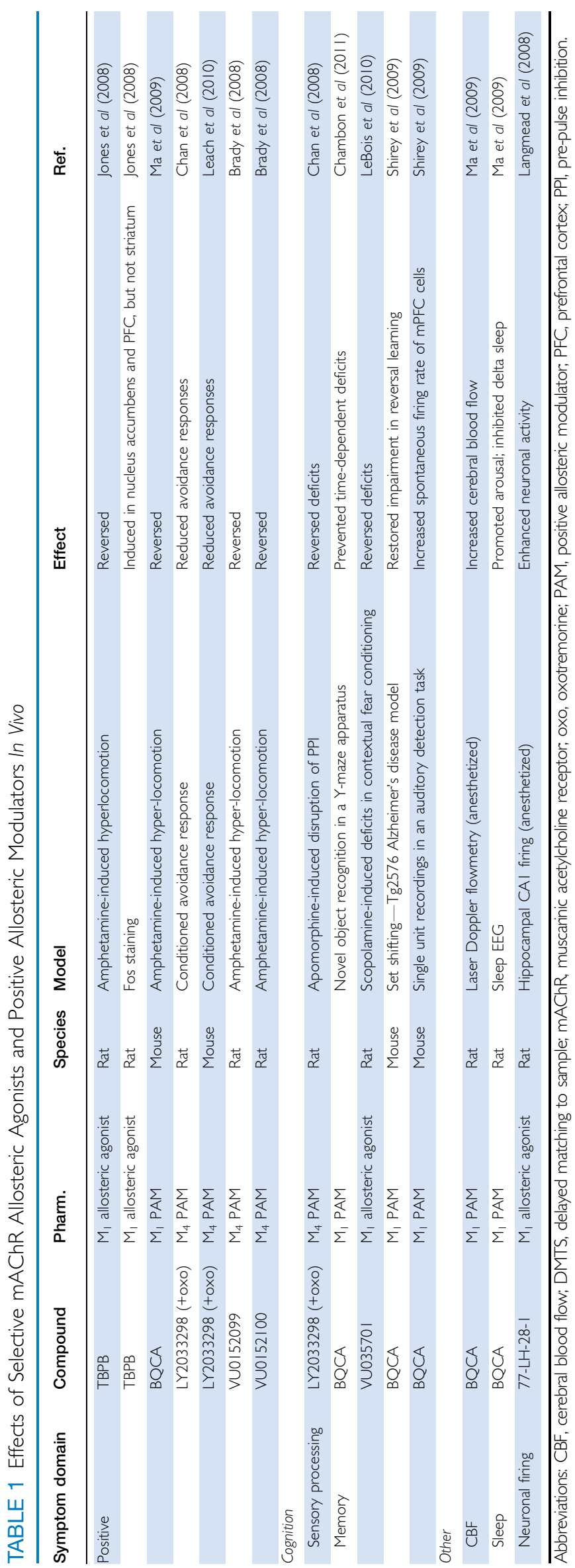


$\mathrm{N}$-desmethylclozapine (NDMC), the biologically active metabolite of the atypical antipsychotic clozapine, possesses high selectivity for $M_{1}$ relative to other mAChR subtypes and can activate $M_{1} m A C h R s$ containing a mutation in the ACh-binding site (Sur et al, 2003). Like clozapine itself, NDMC can potentiate NMDAR activity and induce Fos expression in specific rat forebrain regions, suggesting that allosteric activation of $M_{1}$ mAChRs may account for the distinct clinical efficacy of clozapine (Natesan et al, 2007; Young et al, 1998).

Recently, several systemically active, second-generation $\mathrm{M}_{1}$ allosteric agonists and PAMs are proving to be useful tools for the study of selective activation of $\mathrm{M}_{1} \mathrm{mAChRs}$ in native tissue preparations and in animal models predictive of antipsychotic-like activity and enhancement of cognition. To date, several $\mathrm{M}_{1}$ allosteric agonists have been discovered, including TBPB, 77-LH-28-1, and AC260584. TBPB is a potent $\left(\mathrm{EC}_{50}=280 \mathrm{nM}\right)$ and selective $\left(>30 \mu \mathrm{M} v s \mathrm{M}_{2}-\mathrm{M}_{5}\right)$ $\mathrm{M}_{1}$ allosteric agonist in cell-based systems (Jones et al, 2008). Point mutations in the ACh-binding site that diminish orthosteric agonist activity did not alter the cellular response to TBPB. A Schild analysis of the inhibition of TBPB effects with the orthosteric antagonist atropine established that ТВРB interacts with the orthosteric site in a noncompetitive manner (Jones et al, 2008). These data are consistent with the interpretation that TBPB may act as an allosteric $M_{1}$ agonist as described by the allosteric ternary complex model for the actions of two molecules that interact with distinct sites on a receptor (Christopoulos and Mitchelson, 1997; Jacobson et al, 2010). Nevertheless, future studies are still needed to rule out the possibility that ТВРВ may function as a bitopic agonist, like the novel $\mathrm{M}_{1}$ agonist 77-LH-28-1, by binding to a site on the $\mathrm{M}_{1} \mathrm{mAChR}$, which overlaps with the orthosteric site and with an allosteric site that modulates the affinity of the ACh site (Avlani et al, 2010). $M_{1}$ mAChR activation by TBPB potentiated NMDAR currents in CA1 hippocampal pyramindal cells, a physiological response that is linked to the facilitation of learning and memory (Jones et al, 2008). Functional anatomical studies with TBPB revealed a Fos expression pattern that was similar to the profile of the atypical antipsychotic clozapine, with increased numbers of Fos cells in the mPFC and nucleus accumbens but not the dorsal striatum. In addition, TBPB dose dependently reversed amphetamineinduced hyperlocomotion within a dose range that did not induce side effects associated with the non-selective stimulation of peripheral $\mathrm{mAChRs}$ as measured using a modified Irwin test battery or catalepsy, a preclinical measure of extrapyramidal motor symptoms (Jones et al, 2008).

A second systemically active $\mathrm{M}_{1}$ allosteric agonist, 77-LH28-1, was identified from a series of AC-42 analogs (Langmead et al, 2008) and shown to have high selectivity for $M_{1}$ but weak $M_{3}$ agonist activity (Heinrich et al, 2009). Initial in vitro studies demonstrated that the orthosteric antagonist scopolamine produced parallel rightward shifts in the 77-LH-28-1 concentration response curve (CRC), which led to the interpretation that 77-LH-28-1 may bind at an orthosteric site of $\mathrm{M}_{1}$ (Langmead et al, 2008). Further functional and site-directed mutagenesis studies have confirmed an allosteric mode of agonist action for this ligand, which, interestingly, suggest that 77-LH-28-1 may function as a 'bitopic' agonist as discussed above as a potential mode of action for TBPB (Avlani et al, 2010). 77-LH-28-1 also demonstrated a number of important physiological effects thought to facilitate synaptic plasticity, including increased hippocampal CA1 pyramidal cell firing in vitro and in vivo (Langmead et al, 2008; Buchanan et al, 2010; Jo et al, 2010), and induction of synchronous network activity through increased CA3 hippocampal gamma oscillations alone or in combination with the clinically available AChEI donepezil (Langmead et al, 2008; Spencer et al, 2010).

A structural analog of AC-42, AC-260584, has also been shown to produce effects in animal models of antipsychoticlike activity after systemic dosing (Vanover et al, 2008; Bradley et al, 2010). AC-260584 has been shown to be a potent $\mathrm{M}_{1} \mathrm{mAChR}$ allosteric agonist devoid of agonist activity at the $M_{3} m A C h R$ subtype; however, some $M_{2}$ mAChR agonism has been reported (Bradley et al, 2010). In microdialysis studies, AC-260584, like xanomeline, increased $\mathrm{ACh}$ and DA levels in both the PFC and hippocampus, effects that are thought to be beneficial in schizophrenia (Perry et al, 2001; Li et al, 2007). Systemic administration of AC-260584 induced extracellular-signal regulated kinase-1 (ERK1)/2 activation in the CA1 region of the hippocampus, an effect that was absent in $\mathrm{M}_{1}-\mathrm{KO}$ mice (Bradley et al, 2010). AC-260584 also reversed the hyper-locomotion induced by amphetamine and the noncompetitive NMDAR antagonist MK-801, and suppressed apomorphine-induced climbing without inducing catalepsy or changes in spontaneous locomotor activity (Vanover et al, 2008). AC-260584 also produced efficacy in two preclinical models of learning and memory, the Morris water maze and novel object recognition task (Vanover et al, 2008; Bradley et al, 2010). Unfortunately, interpretation of the enhancement of cognition and antipsychotic-like activity observed with AC-260584 is complicated by off-target actions at other GPCRs, including serotonin 5- $\mathrm{HT}_{2 \mathrm{~A}}, \mathrm{DA}_{2}$, and adrenergic $\alpha 1 \mathrm{~A}$ receptors (Heinrich et al, 2009).

In the last 2 years, a third generation of potent $\left(\mathrm{EC}_{50}\right.$ values $150-200 \mathrm{nM})$, selective ( $>50 \mu \mathrm{M} v s \mathrm{M}_{2}-\mathrm{M}_{5}$ ), and systemically active $M_{1}$ allosteric agonists, VU0186470 and VU0357017, was developed at the Vanderbilt Center for Neuroscience Drug Discovery (Lebois et al, 2010). In contrast to other allosteric modulators of $\mathrm{M}_{1}$ that act at an allosteric site within the seventh TM domain, in vitro studies have demonstrated that VU0186470 and VU0357017 act at a novel allosteric site on the third extracellular loop of the $\mathrm{M}_{1} \mathrm{mAChR}$ (Lebois et al, 2010). These novel allosteric agonists potentiate NMDAR currents and also reverse scopolamine-induced deficits in the acquisition of hippocampus-mediated contextual fear conditioning (Lebois et al, 2010). The evaluation of potential 
preclinical antipsychotic-like activity for these ligands is ongoing.

For the development of $\mathrm{M}_{1}$ PAMs, a major breakthrough was the discovery of BQCA (benzyl quinolone carboxylic acid). Through extensive in vitro studies, BQCA has been shown to be a potent (human $\mathrm{M}_{1} \mathrm{EC}_{50}=845 \mathrm{nM}, 129$-fold leftward shift of the ACh CRC), highly selective $M_{1}$ PAM with no other activity (eg, PAM, agonist, or antagonist) across the other mAChR subtypes when screened at up to $100 \mu \mathrm{M}$ (Ma et al, 2009). BQCA does not bind at the orthosteric ACh-binding site, but increased the affinity of the $\mathrm{M}_{1} \mathrm{mAChR}$ for ACh. Site-directed mutagenesis experiments have identified an allosteric binding site for BQCA involving residues Y179 and W400, which are located on the second (o2) and third (o3) extracellular loops of the receptor (Ma et al, 2009). In in vitro electrophysiology studies, BQCA potentiated the effects of the non-selective $\mathrm{mAChR}$ agonist carbachol to induce inward currents in mPFC pyramidal cells and spontaneous excitatory postsynaptic currents, and these effects were not observed in $\mathrm{M}_{1}$-KO mice (Shirey et al, 2009). Moreover, systemic treatment with BQCA robustly increased firing rates in vivo as measured by single unit recordings in $\mathrm{mPFC}$ pyramidal cells (Shirey et al, 2009). BQCA also has favorable pharmacokinetics and central nervous system exposure for in vivo studies. For example, BQCA reversed deficits in mPFCdependent discrimination reversal learning in a transgenic mouse model of AD (Shirey et al, 2009). In addition, BQCA reversed the scopolamine-induced deficits in the acquisition of contextual fear conditioning similar to the effects observed with $M_{1}$ allosteric agonists; improved novel object recognition in a Y-maze task; and altered sleep architecture by enhancing wakefulness states and decreasing delta sleep (Ma et al, 2009; Chambon et al, 2011). Comparable to the preclinical profile of xanomeline and clozapine, BQCA increased Fos expression in the forebrain and dose dependently reversed amphetamine-induced hyper-locomotion in mice (Ma et al, 2009). Surprisingly, BQCA enhanced blood flow in the cerebral cortex, a function previously associated with activation of non-neuronal $\mathrm{M}_{5} \mathrm{mAChRs}$ (Yamada et al, 2001a, 2003). This finding further highlights the need for subtype-selective tools to clarify the functions of the different $\mathrm{mAChR}$ subtypes in vivo. Collectively, selective activation of $M_{1}$ by both $M_{1}$ allosteric agonists and PAMs is sufficient to mimic some of the effects of xanomeline and clinical available antipsychotics in animal models that are relevant to clinical efficacy. These studies also support the idea that $\mathrm{M}_{1}$ activation may have a critical role in $\mathrm{mPFC}$-dependent cognitive functions and suggest that $\mathrm{M}_{1}$ allosteric activators may serve as an important approach for the treatment of the prefrontal cortical deficits observed in schizophrenic patients.

$M_{4}$ positive allosteric modulators. Significant advancement has also been made in the discovery of $\mathrm{M}_{4}$ allosteric activators with central penetration and suitable physiochemical properties for preclinical studies, allowing for further delineation of the relative contributions of $\mathrm{M}_{1}$ and $\mathrm{M}_{4}$ to the preclinical and clinical efficacy of xanomeline (see Table 1). Thiochrome, an oxidation product and metabolite of thiamine, was the first $\mathrm{M}_{4}$ PAM to be reported in the literature but possessed unsuitable properties for studies in vivo (Lazareno et al, 2004). A major advance in the development of selective $\mathrm{M}_{4} \mathrm{mAChR}$ allosteric activators was the discovery of LY2033298, a highly selective $\mathrm{M}_{4}$ PAM with no detectable activity at any of the other $\mathrm{mAChR}$ subtypes and suitable properties for in vivo dosing (Chan et al, 2008). LY2033298 does not directly activate $\mathrm{M}_{4} \mathrm{mAChRs}$, but, based on site-directed mutagenesis studies, robustly potentiates the response of ACh through binding at residue F186 in the third extracellular loop (o3) of the receptor (Nawaratne et al, 2010). However, when the in vitro potency of LY2033298 was assessed by $\left[{ }^{3} \mathrm{H}\right]$ oxotremorine-M potentiation in rat $\mathrm{M}_{4} \mathrm{mAChR}$ membranes, there was a 5- to 6fold reduction in comparison with studies completed in human $\mathrm{M}_{4} \mathrm{mAChR}\left(\mathrm{hM}_{4}\right)$ membranes $\left(\mathrm{hM}_{4} \mathrm{EC}_{50}=8 \mathrm{nM}\right.$; Chan et al, 2008). Interestingly, LY2033298 had no effects when administered alone in preclinical studies, but robustly potentiated the effects of a sub-threshold dose of the nonselective $\mathrm{mAChR}$ agonist oxotremorine to reverse the apomorphine-induced disruption of PPI and the inhibition of conditioned avoidance responding (Chan et al, 2008; Leach et al, 2010). In early neurochemical studies using in vivo microdialysis techniques, LY2033298 also potentiated oxotremorine-stimulated DA release in the PFC but not nucleus accumbens. The lower potency of LY2033298 at the rat $\mathrm{M}_{4} \mathrm{mAChR}$ was speculated as a potential explanation for the lack of efficacy observed with the compound alone when used in vivo. However, the reported effects of LY2033298 in animal models predictive of antipsychotic-like activity provided important support for further development of other $\mathrm{M}_{4}$ PAMs.

Recently, the discovery of the highly selective $\mathrm{M}_{4}$ PAM VU0010010 with an $\mathrm{EC}_{50}$ of $400 \mathrm{nM}$ for potentiation of ACh effects at the rat $M_{4}$ and a 47 -fold leftward shift in the functional ACh response curve ( $>30 \mu \mathrm{M} v s \mathrm{M}_{1}-\mathrm{M}_{3}, \mathrm{M}_{5}$ ) was reported (Shirey et al, 2008). Based on a number of in vitro pharmacological studies, VU0010010 was shown to act through an allosteric site to increase the efficiency of the coupling of the $\mathrm{M}_{4} \mathrm{mAChR}$ to G-proteins and the affinity of the $\mathrm{M}_{4}$ mAChR for ACh (Shirey et al, 2008). In electrophysiological studies, VU100010 potentiates the carbacholinduced depression of synaptic transmission at excitatory but not inhibitory hippocampal CA1 synapses (Shirey et al, 2008). While VU100010 represented an important tool for cell-based and slice physiology studies, this ligand had unsuitable physicochemical properties for formulation and in vivo dosing (Shirey et al, 2008). Chemical optimization of VU100010 resulted in the discovery of VU0152099 and VU0152100, two related $\mathrm{M}_{4}$ PAMs with rat $\mathrm{M}_{4} \mathrm{EC}_{50}$ values for potentiation of ACh responses of approximately $400 \mathrm{nM}$ (30- to 70-fold leftward shift of the ACh CRC). Both $\mathrm{M}_{4}$ PAMs showed high mAChR subtype selectivity for $M_{4}$ ( $>30 \mu \mathrm{M} v s \mathrm{M}_{1}-\mathrm{M}_{3}$, and $\mathrm{M}_{5}$ ) relative to the other mAChRs 
and further functional selectivity in a screen of 15 other GPCRs that are highly expressed in the brain (Brady et al, 2008). VU0152099 and VU0152100 enhanced $M_{4}$ receptor affinity for ACh, without competing for the orthosteric ACh-binding site (Brady et al, 2008). Most importantly, these novel $\mathrm{M}_{4}$ PAMs are centrally penetrant, with pharmacokinetic properties ideal for studies in animal models of psychosis and cognition. Both VU0152100 and VU0152099 produced a robust reversal of amphetamineinduced hyper-locomotion (Brady et al, 2008) and VU0152100 reversed amphetamine-induced disruptions in the acquisition of contextual fear conditioning in rats (Byun et al, 2011). The in vivo effects of these $\mathrm{M}_{4}$ PAMs were observed when administered alone, indicating that there is sufficient endogenous $\mathrm{ACh}$ within the circuitry mediating these behaviors to observe modulation by an $\mathrm{M}_{4}$ PAM mechanism. The studies with novel $\mathrm{M}_{4}$ PAMs provide critical support for the hypothesis that selective activation of $\mathrm{M}_{4}$ is also a viable target for the development of novel antipsychotic treatments.

$M_{5}$ positive allosteric modulators. As highlighted earlier from KO mice studies, the $\mathrm{M}_{5} \mathrm{mAChR}$ represents another compelling target for the development of novel antipsychotics. However, the lack of subtype-selective ligands has limited our current understanding of the function of this mAChR, relative to $M_{1}$ and $M_{4}$, in circuitry thought to be disrupted in schizophrenia. Recently, chemical optimization of VU0119498, a pan- $\mathrm{M}_{1} / \mathrm{M}_{3} / \mathrm{M}_{5} \mathrm{mAChR}$ PAM, resulted in the discovery of VU0238429, the first $\mathrm{M}_{5}$-preferring mAChR PAM (Bridges et al, 2009). VU0238429 shows moderate potency, with a 14-fold shift in ACh the CRC $\left(\mathrm{M}_{5} \quad \mathrm{EC}_{50}=1.1 \mu \mathrm{M}\right)$ and in vitro selectivity $(>30 \mu \mathrm{M} v \mathrm{~s}$ $\left.M_{1}-M_{4}\right)$. It also enhances the affinity of the $M_{5} m A C h R$ for ACh, but does not compete for the ACh-binding site (Bridges et al, 2009). More recently, further optimization of this first $M_{5}$ PAM has produced VU0400265, a fully selective $\mathrm{M}_{5}$ PAM in recombinant systems with comparable potency in vitro $\left(\mathrm{M}_{5} \mathrm{EC}_{50}=1.9 \mu \mathrm{M}\right)$ (Bridges et al, 2010). Future in vivo studies with these $\mathrm{M}_{5}$-selective PAMs hold promise for a better appreciation of the role of $\mathrm{M}_{5}$ in preclinical models of antipsychotic-like activity and cognitive enhancement.

\section{Potential Challenges with mAChR Allosteric Activators for the Treatment of Schizophrenia}

As discussed under the Introduction, optimal cholinergic signaling for affective and cognitive functions may be region- and task-specific. While the regional levels of cholinergic signaling in schizophrenic patients remain unclear, tonic enhancement of cholinergic neurotransmission by an $\mathrm{mAChR}$ agonist may actually limit improvements in the different symptoms observed in schizophrenic patients. If this is the case, mAChR PAMs may provide a more physiologically relevant modulation of regional and temporal endogenous cholinergic signaling for effective treatment. On the other hand, if the levels of cholinergic neurotransmission are decreased in schizophrenic patients, similar to dementia patients, then there may not be sufficient cholinergic tone to observe efficacy with mAChR PAMs. Future clinical studies with $\mathrm{mAChR}$ agonists and PAMs are needed to confirm which of these approaches will be more effective for the treatment of the different symptom clusters associated with schizophrenia.

While the preclinical characterization of subtype-selective allosteric $\mathrm{mAChRs}$ suggests a potential therapeutic approach for the symptoms associated with schizophrenia, there are several potential challenges to this approach that merit additional evaluation. First, the degree of subtype selectivity of these mAChR allosteric activators must be confirmed further in animal models as well as in the clinic. Extensive studies in recombinant and native system preparations have demonstrated that these mAChR allosteric activators show greater subtype selectivity relative to orthosteric mAChR agonists. However, $\mathrm{mAChR}$ allosteric activators, as reported with the $\mathrm{M}_{4} \mathrm{mAChR}$ PAM thiochrome, may bind with comparable affinities to allosteric sites on multiple $\mathrm{mAChR}$ subtypes and show subtype selectivity through selective cooperativity with other orthosteric site ligands (Lazareno et al, 2004; Conn et al, 2009). Under these circumstances, the selectivity of thiochrome and other $\mathrm{mAChR}$ allosteric modulators may fluctuate based on the system in which their effects are assessed. To clarify this important issue, detailed binding studies using radioligands selective for the allosteric sites, site-directed mutagensis, and measurements of the effects on the binding of orthosteric site ligands will be important for a complete characterization of these novel $\mathrm{mAChR}$ allosteric activators.

An additional concern with the observed selectivity of mAChR PAMs is the potential for differential selectivity in the presence of different orthosteric agonists, or probe dependence (Kenakin, 2008). As reported previously by our group and others using the $\mathrm{M}_{4} \mathrm{mAChR}$ PAM LY2033298 and analogs, the selectivity of these ligands at the five $\mathrm{mAChR}$ subtypes is different when used in combination with the endogenous ligand $\mathrm{ACh}$ and other orthosteric agonists, like oxotremorine (Digby et al, 2010). As shown with LY2033298, co-administration of a sub-threshold dose of the orthosteric $\mathrm{mAChR}$ agonist oxotremorine was required to observe efficacy in animal models and may also be necessary for clinical efficacy. While not all mAChR PAMs require combination treatment with an orthosteric mAChR agonist for efficacy, this issue points to the importance of broadly characterizing the functional selectivity of mAChR PAMs with different chemical classes of orthosteric mAChR agonists.

Previous studies have reported that allosteric $\mathrm{mAChR}$ activators can differentially activate specific signaling pathways and demonstrate clear ligand-directed trafficking of receptor signaling (LDTRS), comparable to the action of some orthosteric mAChR agonists (see Digby et al, 2010). For example, in a previous study, the $\mathrm{M}_{1}$-selective $\mathrm{mAChR}$ PAMs VU0029767 and VU0090157 were reported to robustly potentiate ACh-induced calcium mobilization 
(Marlo et al, 2009). In addition, VU0090157 also potentiated the ACh-induced activation of phospholipase-D (PLD) and phosphatidylinositol (PI) hydrolysis, whereas VU0029767 produced little to no effect on $\mathrm{M}_{1}$-induced increases in PLD activity and PI hydrolysis. These findings are consistent with the interpretation that VU0029767 may induce $M_{1}$ receptor conformation changes that cannot efficiently form signaling complexes with non- $\mathrm{G} \alpha_{\mathrm{q}}$ signaling partners (Marlo et al, 2009). An allosteric mAChR agonist or PAMinduced LDTRS may provide tremendous functional selectivity for various effector systems that could translate in the future to effective strategies for the treatment of different symptoms in schizophrenia. However, this phenomenon also raises the potential for more complicated efficacy profiles with these allosteric ligands. Thus, it will be increasingly important to use a multi-assay approach for a complete characterization of the in vitro and in vivo effects of these novel allosteric mAChR activators.

To date, the assessment of in vivo efficacy with allosteric mAChR ligands has been conducted after an acute, single dose administration of a compound alone or in combination with a low dose of an orthosteric agonist. As the action of mAChR PAMs depends on the activation of the mAChR subtype by $\mathrm{ACh}$, these ligands may preserve a level of activity dependence in contrast to the sustained activation with an agonist. Under chronic dosing regimes, direct-acting $\mathrm{mAChR}$ receptor agonists can produce receptor desensitization and tolerance, whereas mAChR PAMs are postulated to not produce these effects, or at least not to the same degree. However, it should be noted that benzodiazepines, which act as allosteric potentiators of $\mathrm{GABA}_{\mathrm{A}}$ receptors, can also induce tolerance after repeated dosing in some preclinical models and in the clinic (File, 1985; Costa et al, 1995). Yet, GABA can produce robust desensitization of the $\mathrm{GABA}_{\mathrm{A}}$ receptor within milliseconds whereas benzodiazepines do not. Moreover, because of the fundamentally different natures of these classes of receptors, it may not be valid to directly compare the actions of PAMs at ion channels with the action of mAChR PAMs, which signal through G-proteins. Thus, future studies are needed to evaluate the efficacy of mAChR allosteric activators, both agonists and PAMs, after chronic dosing in multiple preclinical models.

\section{ROLE OF NICOTINIC RECEPTOR SUBTYPES IN SCHIZOPHRENIA}

Numerous clinical and preclinical findings suggest that disruptions in central nicotinic cholinergic transmission may be associated with the symptoms observed in individuals with schizophrenia. There is a significantly higher incidence of cigarette smoking among individuals with schizophrenia relative to the general population or in individuals with other psychiatric disorders (Lohr and Flynn, 1992; De Leon et al, 1995; Campo-Arias et al, 2006). Smoking behavior in schizophrenia is also reported to be independent of antipsychotic treatment and frequently observed prior to the initiation of antipsychotic therapies (De Leon et al, 2002). While the underlying causes for the higher rates of smoking in schizophrenia remain unclear, acute nicotine exposure has been shown to improve cognition, particularly in the domains of attention and vigilance, in animals, healthy volunteers, and in smoking and non-smoking schizophrenic patients (Levin et al, 1992; Rezvani and Levin, 2001; Levin, 2002; Avila et al, 2003; Sacco et al, 2005; AhnAllen et al, 2008; Barr et al, 2008; Jubelt et al, 2008). For example, in schizophrenic patients and their relatives, nicotine can transiently improve deficits in P50 auditory gating performance and smooth pursuit eye movements, two clinical measures of sensory information processing (Klein and Andersen, 1991; Adler et al, 1992, 1993). Moreover, a positive correlation has been reported between disruptions in P50 auditory gating function and the severity of cognitive impairments in schizophrenic patients (Erwin et al, 1998). In addition, several polymorphisms in the $\alpha_{7}$ nAChR gene (CHRNA7) have been linked to P50 gating deficits in individuals with schizophrenia (Freedman et al, 1997, 2001; Stassen et al, 2000; Leonard et al, 2002). In a recent study by Mexal et al (2010), both CHRNA7 mRNA and protein expression were reported to be decreased in schizophrenic non-smokers relative to controls; however, in schizophrenic smokers, the levels of CHRNA7 mRNA and protein expression were normal relative to controls. Similar auditory gating deficits observed in the DBA/2 mouse strain have been correlated with decreased levels of hippocampal $\alpha_{7}$ nAChRs and a polymorphism associated with their $\alpha_{7}$ nAChR gene (Stevens et al, 1996; Leonard et al, 1998). The nicotine-mediated normalization of auditory gating deficits in DBA/ 2 mice can be blocked by $\alpha$-bungarotoxin, a selective $\alpha_{7}$ nAChR antagonist, but not by mecamylamine, a selective $\alpha_{4} \beta_{2} \mathrm{nAChR}$ antagonist (Stevens and Wear, 1997; Stevens et al, 1998).

Sensorimotor gating studies in schizophrenic patients have revealed an association between cigarette smoking and enhanced PPI (George et al, 2006; Rabin et al, 2009; Woznica et al, 2009). Smoking cessation, on the other hand, selectively impaired visuospatial working memory and attentional deficits in schizophrenia patients; the improvements in performance following smoking reinstatement were prevented by pretreatment with mecamylamine (Sacco et al, 2005). However, in non-smoking individuals with schizophrenia or controls, mecamylamine did not alter performance on tests of attention, working memory, and executive function (Sacco et al, 2006). Unfortunately, the effects of nicotine are highly transient and limited with repeated dosing; thus nicotine is unsuitable as a treatment for schizophrenic patients (Adler et al, 1992, 1993; Stevens and Wear, 1997). Nicotine also has other limitations, including high abuse liability and undesirable effects on the cardiovascular system (Benowitz, 1988; Benowitz and Gourlay, 1997).

Recently, deletions at the $\alpha_{7}$ nAChR locus were shown to be linked to high risk (odds ratio 11.54) for schizophrenia and psychosis. However, this genetic finding was identified 
in less than $0.2 \%$ of the schizophrenic patients tested, suggesting that only a small proportion of individuals with schizophrenia carry deletions in 15q13.3 (Stefansson et al, 2008). To date, genetic linkage studies for $\alpha_{4} \beta_{2}$ nAChRs and schizophrenia have been even less reproducible, with no associations found between the individual CHRNA4 and CHRNB2 genes and this illness; only one study reported a significant combined $\alpha_{4}$ and $\beta_{2}$-subunit gene interaction with schizophrenia (De Luca et al, 2006; Kishi et al, 2008).

The connection between schizophrenia and nAChRs, especially $\alpha_{7} \mathrm{nAChRs}$, is supported by postmortem immunohistochemical and binding studies that revealed reduced $\alpha_{7}$ nAChR levels in many brain regions thought to be affected in schizophrenia, including the hippocampus, the thalamic reticular nucleus, and the cingulate cortex (Freedman et al, 1995; Guan et al, 1999; Court et al, 1999; Marutle et al, 2001). However, similar changes were not reproducibly observed with $\alpha_{4}$ or $\beta_{2}$-subunits (Breese et al, 2000; MartinRuiz et al, 2003). While nicotine exposure increases highaffinity and low-affinity nAChR binding, such increases cannot explain the decreased $\alpha_{7}$ nAChR levels observed in schizophrenic patients or the lack of effects on $\alpha_{4} \beta_{2} \mathrm{nAChRs}$ (Breese et al, 1997; Court et al, 1998; Gopalakrishnan et al, 1997). Overall, preclinical and clinical findings, along with neuroanatomical and genetic data, support the interpretation that neuronal nAChR signaling is altered in schizophrenia patients. These studies also suggest that the development of selective nAChR subtype activators may lead to important potential therapeutic interventions for this illness.

\section{Preclinical Studies of Full and Partial $\alpha_{7}$ nAChR Agonists}

Over the last decade, important progress has been made in the discovery of multiple full and partial $\alpha_{7} \mathrm{nAChR}$ agonists (see Table 2). DMXB-A (GTS-21) was the first partial $\alpha_{7}$ nAChR agonist with systemic activity to be reported and has been followed by the characterization of numerous $\alpha_{7}$ nAChR agonists as listed in Table 2 . While early $\alpha_{7}$ nAChR ligands, such as DMXB-A, AR-R17779, and ABBF (EVP6124), had less favorable physiochemical properties and showed a lack of true subtype selectivity with off-target effects at hERG, 5- $\mathrm{HT}_{3}$, and/or $\alpha_{4} \beta_{2}$ nAChR (Briggs et al, 1997; Mullen et al, 2000; Boess et al, 2007), recently disclosed $\alpha_{7}$ nAChR agonists possess improved selectivity and properties for oral dosing, including TC-5619 $\left(\mathrm{EC}_{50}=33 \mathrm{nM}, K_{\mathrm{i}}=0.3 \mathrm{nM}\right.$ at rat $\alpha_{7} \mathrm{nAChRs}$, with little to no activity on $\alpha_{4} \beta_{2}$ nAChRs in electrophysiology studies) (Hauser et al, 2009). Despite the limitations of early $\alpha_{7}$ $\mathrm{nAChR}$ agonists, the characterization of these novel ligands has provided exciting opportunities for critical proof-ofconcept studies in animal models and, in some cases, clinical trials for schizophrenia and other neurological disorders.

In recombinant systems and native tissue preparations, studies with DMXB-A and other $\alpha_{7}$ nAChRs agonists have demonstrated that selective activation of $\alpha_{7}$ nAChRs regulates a number of cellular, physiological, and neurochemical responses thought to facilitate synaptic plasticity, learning, and memory. In both in vitro and in vivo studies, $\alpha_{7}$ nAChR agonists enhanced hippocampal LTP, and these effects were blocked by $\alpha_{7} \mathrm{nAChR}$ antagonists at concentrations that have no effect on LTP when administered alone (Mann and Greenfield, 2003; Biton et al, 2007; Lagostena et al, 2008; Söderman et al, 2011). Activation of $\alpha_{7} \mathrm{nAChR}$ agonists also enhanced hippocampal theta oscillation network activity, a physiological function that is disrupted in schizophrenia (Siok et al, 2006). Moreover, deficits in theta burst stimulation-induced LTP, elicited by fimbriafornix lesions of the cholinergic innervation of the hippocampus, were reversed by the $\alpha_{7} \mathrm{nAChR}$ agonist AZD0328 within a dose range that also improved cognitive performance in preclinical working memory tasks (Sydserff et al, 2009). $\alpha_{7}$ nAChR agonists have also been shown to increase ERK phosphorylation and cAMP response element-binding protein phosphorylation in certain brain regions, including the cortex and hippocampus, after acute administration within a dose range that enhanced performance in animal models of cognition, including monkey delayed matching-to-sample, rat social recognition, and mouse inhibitory avoidance (Bitner et al, 2007). These studies are consistent with the interpretation that activation of $\alpha_{7}$ nAChRs increases intracellular calcium and the downstream stimulation of calcium-dependent ERK signal transduction, a cellular pathway that regulates LTP. Finally, several studies have shown enhancement of release of neurotransmitters by $\alpha_{7}$ nAChRs activation in key brain circuits impaired in schizophrenia. Selective activation of $\alpha_{7}$ $\mathrm{nAChRs}$ in the VTA also increased glutamate-mediated DA release in the PFC, a region implicated in the cognitive and negative symptoms of schizophrenic patients (Nanri et al, 1998; Sydserff et al, 2009). Moreover, the $\alpha_{7} \mathrm{nAChR}$ agonist SSR 180711 dose dependently elevated the extracellular levels of $\mathrm{ACh}$ in the hippocampus as well as DA in the PFC in microdialysis studies (Biton et al, 2007; Pichat et al, 2007). It is important to note that enhanced release of $\mathrm{ACh}$ and DA in the PFC is consistent with the ability of $\alpha_{7}$ nAChRs agonists to potentially enhance cognitive performance; however, such augmentation of DA release in the nucleus accumbens might worsen the positive symptoms and lead to increased abuse liability.

Many of these novel $\alpha_{7}$ nAChR agonists have been evaluated in animal models of cognitive enhancement in the domains of sensory information gating, attention, memory, and/or executive functions. To date, one of the most robust and reproducible findings with partial and full $\alpha_{7} \mathrm{nAChR}$ agonists has been the reversal of auditory gating deficits in DBA/2 mice, which, unlike with nicotine, can be observed after repeated dosing (Stevens et al, 1998, 2010; Feuerbach et al, 2009). Moreover, the effects of $\alpha_{7} \mathrm{nAChR}$ agonists on gating deficits can be blocked by $\alpha_{7} \mathrm{nAChR}$ antagonists, but not $\alpha_{4} \beta_{2}$ receptor antagonists (eg, mecamylamine), indicating that the effects are mediated through $\alpha_{7} \mathrm{nAChR}$ 
TABLE 2 Effects of Selective $\alpha_{7}$ nAChR Full and Partial Agonists In Vivo

\begin{tabular}{|c|c|c|c|c|c|c|}
\hline Symptom domain & Compound & Pharm. & Species & Model & Effect & Ref. \\
\hline Positive & PNU-282987 & Full & Rat & Fos & $\begin{array}{l}\text { Induced in nucleus accumbens shell and } \\
\text { PFC, but not striatum }\end{array}$ & Hansen et al (2007) \\
\hline \multicolumn{7}{|l|}{ Negative } \\
\hline & AR-RI7779 & Full & Rat & Social recognition & Increased memory & Van Kampen et al (2004) \\
\hline & SSRI807II & Partial & Rat & $\begin{array}{l}\text { Neonatal PCP-induced impairments in } \\
\text { social novelty discrimination }\end{array}$ & Normalized impairments & Pichat et al (2007) \\
\hline & JN403 & Partial & Mouse & Social recognition & Increased time with novel mouse & Feuerbach et al (2009) \\
\hline & JN403 & Partial & Rat & Social exploration & Increased & Feuerbach et al (2009) \\
\hline & ABBF & Partial & Rat & Social recognition & Improved & Boess et al (2007) \\
\hline & TC-5619 & Full & Mouse & Social recognition in th(tk-)/th(tk-) transgenics & Improved & Hauser et al (2009) \\
\hline \multicolumn{7}{|l|}{ Cognition } \\
\hline \multirow{11}{*}{ Sensory processing } & PHA-5436/3 & Partial & Rat & Amphetamine-induced disruption of auditory gating & Normalized deficit & Wishka et al (2006) \\
\hline & JN403 & Partial & Mouse & Auditory gating deficits in DBA/2 mice & Increased & Feuerbach et al (2009) \\
\hline & SENI 2333 & Full & Rat & Apomorphine-induced disruption of PPI & Normalized deficit & Roncarati et al (2009) \\
\hline & TC-5619 & Full & & Apomorphine-induced disruption of PPI & Reversed & Hauser et al (2009) \\
\hline & SSRI807|I & Partial & Rat & MK80 I-induced persistent latent inhibition & Reversed & Barak et al (2009) \\
\hline & SSRI807II & Partial & Rat & $\begin{array}{l}\text { Neonatal -induced L-NoArg-induced persistent latent } \\
\text { inhibition }\end{array}$ & Reversed & Barak et al (2009) \\
\hline & SSRI807II & Partial & Rat & Amphetamine-induced latent inhibition disruption & Reversed & Barak et al (2009) \\
\hline & GTS-2I/DMXB-A & Partial & Mouse & Auditory gating deficits in DBA/2 mice & Improved & Stevens et al (1998) \\
\hline & GTS-2I/DMXB-A & Partial & Mouse & Auditory gating deficits in DBA/2 mice & Improved (gastric administration) & Simosky et al (200I) \\
\hline & GTS-2I/DMXB-A & Partial & Mouse & Auditory gating deficits in DBA/2 mice & Improved (7-d dosing) & Stevens et al (2010) \\
\hline & MEM3454 & Partial & Rat & Apomorphine-induced disruption of PPI & Improved & Wallace et al (20II) \\
\hline \multirow[t]{2}{*}{ Attention } & MEM3454 & Partial & Rat & Visual signal detection task & Improvement in \% hit accuracy & Rezvani et al (2009) \\
\hline & GTS-2I/DMXB-A & Partial & Monkey & Delayed matching to sample ketamine disruption & Attenuated decreases in accuracies & Buccafusco and Terry (2009) \\
\hline \multirow[t]{2}{*}{ Executive function } & MEM3454 & Partial & Rat & Repeated PCP-induced deficits in attentional set shifting & Improved & Wallace et al (201 I) \\
\hline & MEM3454 & Partial & Rat & Repeated PCP-induced deficits in attentional set shifting & Improved & Wallace et al (20II) \\
\hline \multirow[t]{10}{*}{ Memory } & AZD0328 & Full & Monkey & Spatial delayed response working memory task & Improved at low doses & Castner et al (201 I) \\
\hline & AR-RI7779 & Full & Rat & $\begin{array}{l}\text { Eight-arm radial arm maze - normal and } \\
\text { septohippocampal lesion }\end{array}$ & Improved both & Levin et al (1999) \\
\hline & SSRI807II & Partial & Rat & PCP-induced deficit in a linear maze & Partially reversed & Pichat et al (2007) \\
\hline & SSRI807II & Partial & Mouse & Scopolamine-induced deficits in the Y-maze task & Improved deficits & Redrobe et al (2009) \\
\hline & SSRI807II & Partial & Mouse & Repeated PCP-induced deficits in the modified Y-maze & $\begin{array}{l}\text { Reversed deficits (acute and repeated } \\
\text { dosing) }\end{array}$ & Thomsen et al (2009) \\
\hline & SSRI807II & Partial & Mouse & Neonatal PCP-induced deficits in the modified Y-maze & Reversed deficits & Thomsen et al (2009) \\
\hline & SSRI807II & Partial & Rat & Novel object recognition & Increased memory & Pichat et al (2007) \\
\hline & SSRI807II & Partial & Rat & MK-80 I-induced deficits in novel object recognition & Reversed deficits & Pichat et al (2007) \\
\hline & SSRI807II & Partial & Rat & $\begin{array}{l}\text { Acute PCP-induced deficits in novel object } \\
\text { recognition - PCP-sensitized }\end{array}$ & $\begin{array}{l}\text { Prevented deficits by acute PCP } \\
\text { challenge }\end{array}$ & Pichat et al (2007) \\
\hline & SSRI807II & Partial & Mouse & Novel object recognition & Increased memory & Pichat et al (2007) \\
\hline
\end{tabular}


activation in vivo (Simosky et al, 2001). $\alpha_{7} \mathrm{nAChR}$ agonists have also reversed auditory gating deficits induced by amphetamine or fimbria-fornix lesions of cholinergic innervation of the hippocampus in rats (Wishka et al, 2006). More recently, the partial $\alpha_{7} \mathrm{nAChR}$ agonist SSR180711 was shown to reverse NMDAR antagonistinduced impairments in latent inhibition and novelty discrimination, two other gating and attentional tasks, and these effects were blocked by $\alpha_{7} \mathrm{nAChR}$ antagonists (Barak et al, 2009). Similar to the effects of mAChR activators, $\alpha_{7}$ nAChR agonists have been shown to reverse the apomorphine-induced disruption of PPI (Hauser et al, 2009; Roncarati et al, 2009; Wallace et al, 2011).

Selective activation of $\alpha_{7} \mathrm{nAChRs}$ by full and partial $\alpha_{7}$ $\mathrm{nAChR}$ agonists also produced efficacy across a number of preclinical models of learning and memory, including improvements in passive avoidance responding, novel object recognition, and maze tasks in young and aged rats (Redrobe et al, 2009; Roncarati et al, 2009). Again, the effects of $\alpha_{7} \mathrm{nAChR}$ agonists on memory functions were blocked by co-administration with $\alpha_{7} \mathrm{nAChR}$ antagonists (Roncarati et al, 2009). In non-human primates, $\alpha_{7} \mathrm{nAChR}$ agonists have also enhanced delayed matching-to-sample task and spatial delayed responding (Buccafusco and Terry, 2009; Castner et al, 2011). In contrast to the lack of studies with muscarinic activators in preclinical models of NMDAR hypofunction, $\alpha_{7}$ nAChR agonists such as SSR180711 produced robust efficacy in reversing both acute and chronic NMDAR antagonist-induced deficits in hippocampal and non-hippocampal memory tasks, including object recognition, Morris water maze, and Y-maze in rodents (Wishka et al, 2006; Boess et al, 2007; Pichat et al, 2007; Hashimoto et al, 2008; Thomsen et al, 2009). More recently, the partial $\alpha_{7} \mathrm{nAChR}$ agonist MEM3454 was also reported to reverse the chronic PCP-induced impairments of extradimensional attentional set-shifting in rats (Wallace et al, 2011). The effects of SSR180711 and MEM3454 in these NMDAR disruption models were blocked by $\alpha_{7}$ nAChR antagonists (Pichat et al, 2007; Wallace et al, 2011; Thomsen et al, 2009). Interestingly, $\alpha_{7} \mathrm{nAChR}$ agonists have also produced effects in social recognition tasks, a potential preclinical model of the negative symptoms in schizophrenia (Feuerbach et al, 2009; Boess et al, 2007; Hauser et al, 2009). Finally, in a preclinical model of antipsychotic-like activity, the $\alpha_{7}$ nAChRs agonist PNU-282987 revealed a pattern of Fos induction in forebrain regions similar to atypical antipsychotics (Hansen et al, 2007; Thomsen et al, 2010). Taken together, these preclinical findings suggest that selective activation of $\alpha_{7} \mathrm{nAChRs}$ may provide efficacy across the different symptoms domains of schizophrenia.

Based on the favorable preclinical findings of enhanced cognitive function, antipsychotic-like effects, and safety for several $\alpha_{7} \mathrm{nAChR}$ agonists, these ligands were advanced into clinical trials for schizophrenia, as well as for the cognitive impairments associated with ADHD and mild-to-moderate dementia in $\mathrm{AD}$ (see Table 3). To date, there have been only three clinical studies reported in the literature using the 


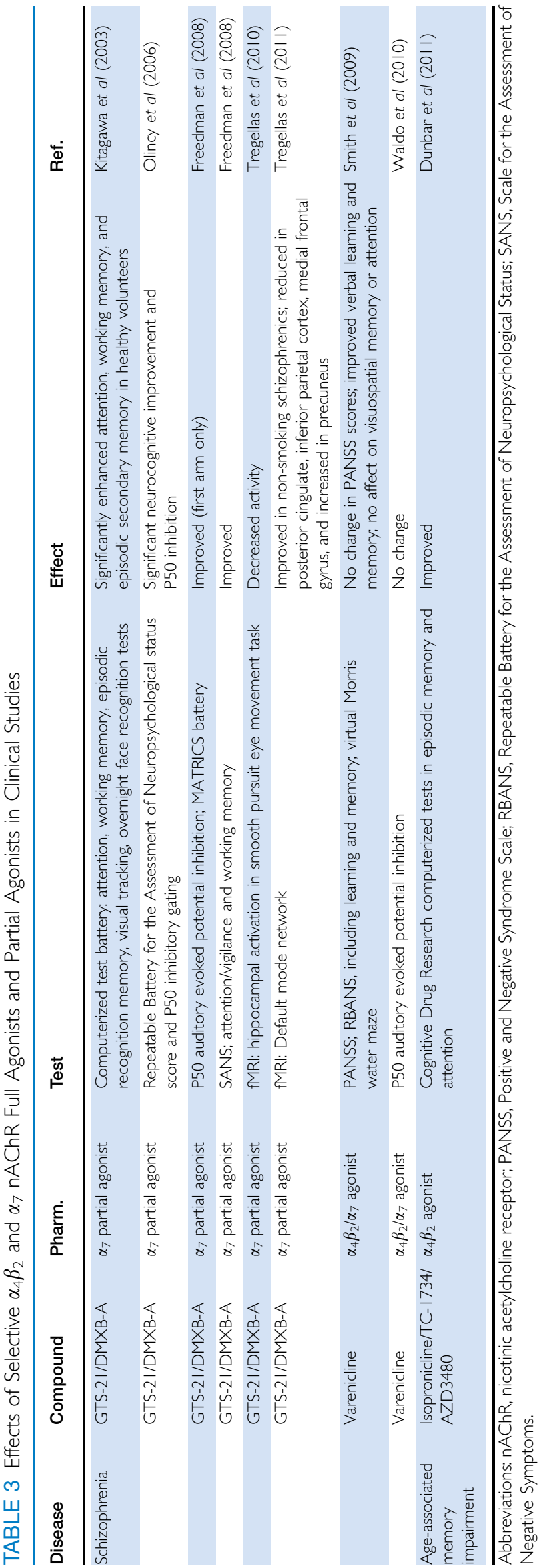

$\alpha_{7}$ nAChR partial agonist DMXB-A. In an initial phase-I randomized, double-blind, placebo-controlled study (18 healthy, non-smoking male volunteers), DMXB-A was administered perorally three times daily over 5 days (Kitagawa et al, 2003). Across all doses, DMXB-A significantly improved performance on a number of cognitive tasks, including immediate and delayed word recall, and correct detection during digit vigilance with increases in reaction time (Kitagawa et al, 2003). DMXB-A also dose dependently enhanced performance in spatial and numeric working memory tasks at doses of up to approximately $1.9 \mathrm{mg} / \mathrm{kg}$ t.i.d. that were well-tolerated over a 5-day treatment session. Next, the effects of DMXB-A were evaluated in a phase-II randomized, double-blind, placebo-controlled cross-over trial with 12 non-smoking schizophrenic patients on concurrent neuroleptic treatment (Olincy et al, 2006). In this trial, DMXB-A significantly reduced P50 auditory gating deficits and enhanced total performance scores on the Repeatable Battery for the Assessment of Neuropsychological Status (RBANS) test, with the largest improvement in attention functions (Olincy et al, 2006). Based on the positive results from the first two DMXB-A trials, another randomized, double-blind, placebo-controlled, phase-II trial was performed (31 nonsmoking schizophrenic patients) over a 4-week period (Freedman et al, 2008). In this cross-over trial design, there were no significant changes in cognitive measures between DMXB-A- and placebo-treated patients over the three treatment arms on the MATRICS Consensus Cognitive Battery. However, there were significant improvements at the higher DMXB-A dose $(150 \mathrm{mg})$ on the Scale for the Assessment of Negative Symptoms (SANS), with a trend toward enhancement on BPRS, particularly in the anhedonia and alogia subscales (Freedman et al, 2008). While it is tempting to conclude that the loss of efficacy over time was due to the possible tachyphylaxis effects of DMXB-A, the findings in this study, like many others, were confounded by a significant practice effect observed across all groups, especially within the MATRICS tasks. During this phase-II trial, patients were also included in functional magnetic resonance imaging studies to determine whether DMXB-A could normalize changes in default mode network and hippocampal activity, two biomarkers of antipsychotic treatment efficacy (Tregellas et al, 2010, 2011). Changes in default mode network activity were evaluated in the context of a polymorphism in CHRNA7, which was previously found to be associated with schizophrenia. DMXB-A treatment was associated with changes in default mode activity as compared with placebo, with reductions in the posterior cingulate, inferior parietal cortex, and medial frontal gyrus, and an increase in precuneus activity. The most robust difference, specifically, reductions posterior cingulate activity, was influenced by the CHRNA7 genotype (Tregellas et al, 2010, 2011). These results suggest normalization of default mode function, but future studies will need to include control subjects for verification of the normal default mode network. In addition, DMXB-A 
TABLE 4 Effects of Selective $\alpha 7$ nAChR Allosteric Positive Allosteric Modulators In Vivo

\begin{tabular}{|c|c|c|c|c|c|c|}
\hline Symptom domain & Compound & Pharm. & Species & Model & Effect & Ref. \\
\hline \multicolumn{7}{|l|}{ Negative } \\
\hline & NS- 1738 & Type-I & Rat & Social recognition test & Improved performance & Timmermann et al (2007) \\
\hline \multicolumn{7}{|l|}{ Cognition } \\
\hline \multirow[t]{2}{*}{ Sensory processing } & PNU-120596 & Type-II & Rat & $\begin{array}{l}\text { Amphetamine-induced deficits in } \\
\text { auditory gating }\end{array}$ & Improved & Hurst et al (2005) \\
\hline & A-867744 & Type-II & Mouse & $\begin{array}{l}\text { Deficits in auditory-evoked potentials } \\
\text { in } D A B / 2 \text { strain }\end{array}$ & Reversed & Faghih et al (2009) \\
\hline \multirow[t]{2}{*}{ Memory } & NS- 1738 & Type-I & Rat & $\begin{array}{l}\text { Scopolamine-induced deficit in Morris } \\
\text { water-maze }\end{array}$ & $\begin{array}{l}\text { Improved deficit in } \\
\text { acquisition }\end{array}$ & Timmermann et al (2007) \\
\hline & $X Y-4083$ & Type-I & Rat & Eight-arm radial maze & Improved & Ng et al (2007) \\
\hline
\end{tabular}

significantly decreased hippocampal activation during a smooth pursuit eye movement task. These findings are consistent with the previously established function of $\alpha_{7}$-nicotinic receptors on the inhibitory interneurons in the hippocampus (Tregellas et al, 2010, 2011).

\section{Preclinical Studies of $\alpha_{7}$ nAChR Positive Allosteric Modulators}

While the development of full and partial $\alpha_{7} \mathrm{nAChR}$ agonists has led to a greater understanding of the functional significance of selective activation of $\alpha_{7} \mathrm{nAChRs}$ in preclinical models and in clinical populations, these studies have also raised many questions. One key concern involves the possibility of limited or diminished efficacy after chronic dosing owing to rapid desensitization of $\alpha_{7}$ nAChRs in vivo and adverse effects due to off-target activity at other nAChRs. Similar to the challenges observed with orthosteric mAChR agonists, the development of subtype-selective allosteric modulators for the nAChRs may provide several advantages for therapeutic development. To date, a number of $\alpha_{7}$-selective nAChR PAMs have been reported; they can be divided into two functionally distinct types based on the way in which these ligands affect the time course of agonist-evoked currents in electrophysiology studies (Gronlien et al, 2007) (see Table 4). In general, both types of nAChR PAMs increase the potency and efficacy of agonists. Type-I nAChR PAMs potentiate the ACh-induced peak current, while having little or no effect on ACh-induced desensitization and deactivation processes. Examples of type-I PAMs include NS-1738 (eg, $\mathrm{EC}_{50}=3.4 \mu \mathrm{M} ; 2$ - to 3-fold shift) and XY-4083 (Ng et al, 2007; Timmermann et al, 2007). Type-II nAChR PAMs potentiate ACh-induced peak current and prolong the time course of the agonist-evoked response by suppressing the extent of fast desensitization and by increasing the contribution of a slow desensitizing current. Two representative type-II PAMs include PNU-120596 (eg, $\mathrm{EC}_{50}=1.5 \mu \mathrm{M}$; fourfold shift) and A-867744 (Hurst et al, 2005; Gronlien et al, 2007; Malysz et al, 2009; Faghih et al, 2009). Interestingly, both type-I and II $\alpha_{7} \mathrm{nAChR}$ PAMs produced efficacy in preclinical models, including reversal of auditory gating deficits in DBA/2 mice or after amphetamine challenge; reversal of MK-801-induced deficits in PPI and other pharmacological disruptions in novelty-induced exploratory activity; Morris water maze; and social interaction (Hurst et al, 2005; Timmermann et al, 2007; Faghih et al, 2009). Interestingly, these preliminary findings have been observed with administration of the nAChR PAMs alone, indicating that there is sufficient cholinergic tone on $\alpha_{7}$ nAChRs for a viable allosteric modulator approach in vivo. There are now several $\alpha_{7}$ nAChR PAMs under clinical development for the treatment of schizophrenia. One of the important considerations for the viability of PAMs in the clinic will be to more fully understand the issue of whether sustained $\mathrm{Ca}^{2+}$ entry resulting from delayed $\alpha_{7} \mathrm{nAChR}$ desensitization by type-II PAMs will result in $\mathrm{Ca}^{2+}$-induced cytotoxicity as there have been conflicting results in the literature $(\mathrm{Ng}$ et al, 2007; $\mathrm{Hu}$ et al, 2009).

\section{Preclinical Studies of $\alpha_{4} \beta_{2} n A C h R$ Agonists}

Beyond the clear role of $\alpha_{7} \mathrm{nAChRs}$ in the underlying auditory gating deficits observed in schizophrenic patients, there is accumulating evidence suggesting that altered $\alpha_{4} \beta_{2}$ $\mathrm{nAChR}$ function may also have a role in the symptoms of this illness. To date, there have been several novel selective $\alpha_{4} \beta_{2}$ nAChR agonists developed for the treatment of cognitive deficits associated with schizophrenia and other neurological disorders (see Table 5), including ABT-418, ABT-089, ABT-594, 5-iodo-A-85380, and TC-1734 (AZD3480; isopronicline) (Arneric et al, 1994; Decker et al, 1994b; Lin et al, 1997; Mukhin et al, 2000; Obinu et al, 2002). Preliminary preclinical studies have shown that selective activation of $\alpha_{4} \beta_{2}$ improves auditory gating deficits 
TABLE 5 Effects of Selective $\alpha_{4} \beta_{2}$ Agonists, nAChR Full Agonists, and Partial Agonists In Vivo

\begin{tabular}{|c|c|c|c|c|c|c|}
\hline Symptom domain & Compound & Pharm. & Species & Model & Effect & Ref. \\
\hline \multicolumn{7}{|l|}{ Cognition } \\
\hline \multirow[t]{3}{*}{ Sensory processing } & ABT-4I8 & Full & Mouse & Auditory-evoked sensory gating in DBA/2 mice & Normalized (second dose ineffective) & Stevens and Wear (1997) \\
\hline & ABT-4I8 & Full & Rat & $\begin{array}{l}\text { Auditory-evoked sensory gating —-fimbria-fornix } \\
\text { lesion }\end{array}$ & Normalized (second dose ineffective) & Stevens and Wear (1997) \\
\hline & 5-lodo-A-85380 & Full & Mouse & Auditory-evoked sensory gating_-DBA/2 mice & Normalized & Wildeboer and Stevens (2008) \\
\hline \multirow[t]{3}{*}{ Attention } & ABT-4I8 & Full & Rat & 5 -CSRTT & Increased accuracy (transient); reduced response latency & Hahn et al (2003) \\
\hline & SIB- $1765 F$ & Partial & Rat & 5-CSRTT & Increased correct responding & Grottick and Higgins (2000) \\
\hline & SIB- $1765 F$ & Partial & Rat & 5-CSRTT & Increased performance speed & Grottick et al (2003) \\
\hline \multirow[t]{11}{*}{ Memory } & ABT-089 & Full & Monkey & DMTS & Improved performance in mature and aged & Decker et al (1997) \\
\hline & ABT-4I8 & Full & Monkey & DMTS & Improved performance & Buccafusco et al (1995) \\
\hline & ABT-4I8 & Full & Monkey & Delayed recall test-after distractions & Increased accuracy; reduced distractibility & Prendergast et al (1998) \\
\hline & ABT-4I8 & Full & Monkey & $\begin{array}{l}\text { Delayed recall test, aged vs young } \\
\text { (transdermal vs i.m.) }\end{array}$ & $\begin{array}{l}\text { Improved performance (patch prolonged improvement } \\
\text { in the young) }\end{array}$ & Prendergast et al (1997) \\
\hline & $\begin{array}{l}\text { TC-1734/isopronicline/ } \\
\text { AZD3480 }\end{array}$ & & Mouse & Novel object recognition & Improved & Obinu et al (2002) \\
\hline & ABT-594 & Partial & Monkey & DMTS & Increased accuracy & Buccafusco et al (2007) \\
\hline & ABT-4I8 & Full & Rat & Morris water maze - septal lesion & Attenuated deficits & Decker et al (1994b) \\
\hline & ABT-4I8 & Full & Mouse & Contextual fear conditioning & Enhanced & Kenney et al (2010) \\
\hline & ABT-4I 8 & Full & Mouse & Inhibitory avoidance & Improved retention & Decker et al (1994a) \\
\hline & ABT-089 & Full & Rat & Morris water maze - septal lesion & Attenuated deficits (repeated dosing) & Decker et al (1997) \\
\hline & ABT-089 & Full & Rat & Inhibitory avoidance & No effect on young or old & Decker et al (1997) \\
\hline
\end{tabular}

Abbreviations: 5-CSRTT, 5-Choice Serial Reaction Time Test; DMTS, Delayed Matching to Sample; nAChR, nicotinic acetylcholine receptor; PPI, pre-pulse inhibition. 
in both DBA/2 mice and in rats (Stevens and Wear, 1997; Wildeboer and Stevens, 2008). In preclinical studies, activation of $\alpha_{4} \beta_{2}$ receptors by selective agonists has no effect on PPI deficits similar to the lack of effects with $\alpha_{7}$ nAChR partial and full agonists (Radek et al, 2010). However, unlike $\alpha_{7} \mathrm{nAChR}$ agonists, $\alpha_{4} \beta_{2}$ nAChR agonists produced robust effects in preclinical models of other attentional functions, such as in the five-choice serial reaction time task, and these effects were only blocked by $\alpha_{4} \beta_{2}$ antagonists such as $\operatorname{Dh} \beta \mathrm{E}$ but not $\alpha_{7}$ antagonists (Blondel et al, 2000; Grottick et al, 2000; Hahn et al, 2003). $\alpha_{4} \beta_{2}$ agonists such as ABT-418 also significantly improved performance in several preclinical models of working memory in rodents and monkeys, and, again, these effects were blocked by $\alpha_{4} \beta_{2}$ antagonists (Buccafusco et al, 1995, 2007; Decker et al, 1997; Prendergast et al, 1997, 1998; Obinu et al, 2002; Levin, 2002; Chan et al, 2007). Furthermore, ABT-418 was shown to enhance hippocampus-mediated tasks, including contextual fear conditioning as well as water maze performance in rats with septal lesions (Decker et al, 1994a, b; Kenney et al, 2010). Currently, there have been no reported clinical findings with $\alpha_{4} \beta_{2}$ nAChRs in patients with schizophrenia. However, a number of ongoing clinical trials are evaluating the effects of $\alpha_{4} \beta_{2} \mathrm{nAChR}$ agonists for the cognitive deficits in schizophrenia, ADHD, and mildto-moderate dementias in $\mathrm{AD}$ patients. In a recent randomized, placebo-controlled study, the $\alpha_{4} \beta_{2}$ agonist TC-1734 (AZD3480; isopronicline) was well-tolerated and robustly improved age-associated memory impairments as measured by assessment through the Cognitive Drug Research computerized test battery and a Subject Global Impression Scale of Cognition (SCI-Cog) (Dunbar et al, 2011) (see Table 3). Finally, varenicline, a clinically approved treatment for smoking cessation, with partial $\alpha_{4} \beta_{2}$ agonist and full $\alpha_{7}$ agonist activity (Mihalak et al, 2006), significantly improved scores on verbal learning and memory tests, but not performance on visual-spatial or attentional performance or PANSS scores; these findings were consistent with previous preclinical data (Smith et al, 2009). However, in a more recent pilot study $(n=6)$, varenicline did not improve P50 auditory gating in schizophrenia patients as compared with placebo, but elicited central side effects (Waldo et al, 2010), which were in line with the potential exacerbation of neuropsychiatric conditions (Kuehn, 2008). Clearly more clinical studies are needed with highly selective nAChR ligands to further elucidate the respective roles of these subtypes in previously reported clinical effects.

\section{Potential Challenges with nAChR Partial Agonists and Allosteric Activators for the Treatment of Schizophrenia}

Current clinical and preclinical studies with $\alpha_{7}$ and $\alpha_{4} \beta_{2}$ nAChR agonists and PAMs suggest that this approach will continue to be successful as a novel treatment strategy for schizophrenia. Many of the concerns raised under the potential challenges of $\mathrm{mAChR}$ allosteric activators are relevant to the development of $\mathrm{nAChR}$ partial agonists and modulators as well. For example, it remains unclear whether the recombinant systems used to develop more subtype-selective nAChR agonists and PAMs sufficiently reflect the expression levels and stoichiometries of the $\alpha_{7}$ and $\alpha_{4} \beta_{2}$ nAChR subunits comprising these two subtypes found in native systems, particularly in clinical populations with chronic nicotine intake. Such potential differences could lead to the development of nAChR ligands with inadequate subtype selectivity for schizophrenic patients. The development of biomarkers for $\alpha_{7}$ and $\alpha_{4} \beta_{2}$ nAChR target engagement and/or target-related efficacy will also be crucial to confirm clear $\alpha_{7}$ or $\alpha_{4} \beta_{2}$ nAChR-mediated effects in future clinical trials for schizophrenia. Moreover, future clinical studies are needed to further understand the broader clinical utility of the selective $\alpha_{7}$ and $\alpha_{4} \beta_{2}$ nAChR ligands for the treatment of the different symptom domains in schizophrenia, beyond the observed clinical efficacy on auditory gating and attentional functions.

While early studies with repeated administration of nicotine revealed diminished efficacy of some clinical endpoints due presumably to rapid receptor desensitization (Griffith et al, 1998; Harris et al, 2004), more recent preclinical and clinical data with $\alpha_{7}$ and $\alpha_{4} \beta_{2}$ nAChR partial agonists and PAMs suggest that efficacy can be sustained with repeated dosing. However, there are lingering questions regarding the underlying mechanism of action of $\alpha_{7}$ and $\alpha_{4} \beta_{2}$ nAChR activators, and whether some or most of the observed effects with these compounds are due to receptor activation or desensitization. For example, the rapid desensitization of $\alpha_{7} \mathrm{nAChR}$ in response to repeated dosing of nicotine and analogs combined with the observations that, at low doses, some nicotinic antagonists induce agonist-like responses suggest that $\alpha_{7}$ nAChR desensitization, rather than activation, may explain some of the observed efficacy with $\alpha_{7}$ agonists (Buccafusco et al, 2009; Picciotto et al, 2008). Furthermore, there are substantial inconsistencies between the high concentrations of nAChR ligands required to activate $\mathrm{nAChR}$-mediated in vitro responses and the considerably lower dose ranges needed to induce behavioral responses in animals and humans. In electrophysiology studies, nicotine and the nAChR antagonists $d$-tubocurarine and $\alpha$-bungarotoxin enhanced hippocampal neuronal excitation (Ropert and Krnjević, 1982). At low doses nAChR antagonists, such as mecamylamine, enhanced performance comparable to nicotine in several learning and memory tasks, including delayed matching-tosample accuracy in monkeys (Buccafusco and Jackson, 1991; Terry et al, 1999), and delayed stimulus discrimination, radial arm maze, and T-maze alternation tasks in rats (Moran, 1993; Levin et al, 1997; Terry et al, 1999). In a recent study by Buccafusco et al (2009), the efficacy of nicotine, cotinine, a major nicotine metabolite, and two analogs of choline, JWB1-84-1 and JAY2-22-33, were compared side-by-side in the delayed matching-to-sample task in monkeys. Interestingly, the performance levels in this cognitive task directly correlated with the degree of 
receptor desensitization induced by each of these nAChR agonists and similar to responses in rodents (Sood et al, 2007). If this desensitization hypothesis is correct, then the development of ligands that desensitize the nAChRs, especially $\alpha_{7}$ nAChR, without activation would be a more tractable approach for the treatment of cognitive deficits in schizophrenic patients. However, other findings, including rapid upregulation of $\alpha_{7} \mathrm{nAChRs}$ upon their activation, support the interpretation that $\alpha_{7} \mathrm{nAChR}$ agonists produce their effects through activation of the receptors. Future in vivo studies using novel nAChR PAMs, such as SazetidineA, that directly desensitize nAChRs without activation (Xiao et al, 2006) are needed to better understand the mechanism of action of nAChR agonists in animal models and in the clinic. Finally, future studies are also needed to assess the possible interactions between the different $\mathrm{mAChR}$ and nAChR subtypes in the modulation of the schizophreniarelated circuitry, as well as possible synergistic effects with clinically available antipsychotics.

\section{FUTURE RESEARCH DIRECTIONS}

Preclinical and clinical findings with subtype-selective $\mathrm{mAChR}$ and $\mathrm{nAChR}$ activators are providing important validation for the cholinergic hypothesis of schizophrenia and novel approaches for the treatment of the cognitive, positive, and negative symptoms. In addition, these subtypeselective $\mathrm{mAChR}$ and $\mathrm{nAChR}$ activators are serving as critical tools to better understand the relative roles of the different receptor subtypes in the observed efficacy of non-selective muscarinic and nicotinic receptor agonists in vivo. For the modulation of $\mathrm{mAChRs}$, current data suggest that selective $M_{1}$ and $M_{4}$ allosteric agonists and PAMs may be efficacious for the treatment of the cognitive impairments as well as the positive symptoms. However, additional studies are needed to further understand the effects of these compounds in preclinical models of the negative symptoms and different aspects of PFC- and hippocampus-mediated cognition. For the nicotinic cholinergic system, preclinical and clinical studies with selective agonists of the $\alpha_{7}$ and $\alpha_{4} \beta_{2}$ nAChRs suggest that central activation of these receptors may be especially efficacious for the cognitive deficits observed in individuals with schizophrenia.

\section{ACKNOWLEDGEMENTS}

This work was supported by funding from NIMH/NIH.

\section{DISCLOSURE}

The authors declare no conflict of interest.

\section{REFERENCES}

Abrams P, Andersson KE, Buccafusco JJ, Chapple C, de Groat WC, Fryer AD et al (2006). Muscarinic receptors: their distribution and function in body systems, and the implications for treating overactive bladder. Br J Pharmacol 48: 565-578.
Adler LE, Hoffer LJ, Griffith J, Waldo MC, Freedman R (1992). Normalization by nicotine of deficient auditory sensory gating in the relatives of schizophrenics. Biol Psychiatry 32: 607-616.

Adler LE, Hoffer LJ, Wiser A, Freedman R. (1993). Cigarette smoking normalizes auditory physiology in schizophrenics. Am J Psychiatry 150: 1856-1861.

Agid O, Kapur S, Arenovich T, Zipursky RB (2003). Delayed-onset hypothesis of antipsychotic action: a hypothesis tested and rejected. Arch Gen Psychiatry 60: 1228-1235.

Agid O, Kaour S, Warrington L, Loebel A, Siu C (2008). Early onset of antipsychotic response in the treatment of acutely agitated patients with psychotic disorders. Schizophr Res 102: 241-248.

AhnAllen CG, Nestor PG, Shenton ME, McCarley RW, Niznikiewicz MA (2008). Early nicotine withdrawal and transdermal nicotine effects on neurocognitive performance in schizophrenia. Schizophr Res 100: 261-269.

Aigner TG, Mishkin M (1986). The effects of physostigmine and scopolamine on recognition memory in monkeys. Behav Neural Biol 45: 81-87.

Albuquerque EX, Pereira EF, Alkondon M, Rogers SW (2009). Mammalian nicotinic acetylcholine receptors: from structure to function. Physiol Rev 89: 73-120.

American Psychiatric Association (2000). Diagnostic and Statistical Manual of Mental Disorders, 4th edn. American Psychiatric Publishing: Washington, DC.

Anagnostaras SG, Murphy GG, Hamilton SE, Mitchell SL, Rahnama NP, Nathanson NM et al (2003). Selective cognitive dysfunction in acetylcholine M1 muscarinic receptor mutant mice. Nat Neurosci 6: 51-58.

Andersen MB, Fink-Jensen A, Peacock L, Gerlach J, Bymaster F, Lundbaek JA et al (2003). The muscarinic M1/M4 receptor agonist xanomeline exhibits antipsychotic-like activity in Cebus apella monkeys. Neuropsychopharmacology 28: 1168-1175.

Anderson DJ, Malysz J, Grønlien JH, El Kouhen R, Håkerud M, Wetterstrand C et al (2009). Stimulation of dopamine release by nicotinic acetylcholine receptor ligands in rat brain slices correlates with the profile of high, but not low, sensitivity alpha4beta2 subunit combination. Biochem Pharmacol 78: 844-851.

Araya R, Noguchi T, Yuhki M, Kitamura N, Higuchi M, Saido TC et al (2006). Loss of M5 muscarinic acetylcholine receptors leads to cerebrovascular and neuronal abnormalities and cognitive deficits in mice. Neurobiol Dis 24: 334-344.

Arneric SP, Sullivan JP, Briggs CA, Donnelly-Roberts D, Anderson DJ, Raszkiewicz $\mathrm{JL}$ et al (1994). (S)-3-methyl-5-(1-methyl-2-pyrrolidinyl) isoxazole (ABT 418): a novel cholinergic ligand with cognition-enhancing and anxiolytic activities: I. In vitro characterization. J Pharmacol Exp Ther 270: 310-318.

Avila MT, Sherr JD, Hong E, Myers CS, Thaker GK (2003). Effects of nicotine on leading saccades during smooth pursuit eye movements in smokers and nonsmokers with schizophrenia. Neuropsychopharmacology 28: 2184-2191.

Avlani VA, Langmead CJ, Guida E, Wood MD, Tehan BG, Herdon HJ et al (2010). Orthosteric and allosteric modes of interaction of novel selective agonists of the M1 muscarinic acetylcholine receptor. Mol Pharmacol 78: 94-104.

Barak S, Arad M, De Levie A, Black MD, Griebel G, Weiner I (2009). Pro-cognitive and antipsychotic efficacy of the alpha7 nicotinic partial agonist SSR180711 in pharmacological and neurodevelopmental latent inhibition models of schizophrenia. Neuropsychopharmacology 34: 1753-1763.

Barr RS, Culhane MA, Jubelt LE, Mufti RS, Dyer MA, Weiss AP et al (2008). The effects of transdermal nicotine on cognition in nonsmokers with schizophrenia and nonpsychiatric controls. Neuropsychopharmacology 33: 480-490.

Basile AS, Fedorova I, Zapata A, Liu XG, Shippenberg T, Duttaroy A et al (2002). Deletion of the M5 muscarinic acetylcholine receptor attenuates morphine reinforcement and withdrawal but not morphine analgesia. Proc Natl Acad Sci USA 99: 11452-11457.

Beneyto M, Lewis DA (2011). Insights into the neurodevelopmental origin of schizophrenia from postmortem studies of prefrontal cortical circuitry. Int J Dev Neurosci 29: 295-304.

Benowitz NL (1988). Toxicity of nicotine: implications with regard to nicotine replacement therapy. Prog Clin Biol Res 261: 187-217.

Benowitz NL, Gourlay SG (1997). Cardiovascular toxicity of nicotine: implications for nicotine replacement therapy. J Am Coll Cardiol 29: 1422-1431.

Bird ED, Spokes EG, Barnes J, MacKay AV, Iversen LL, Shepherd M (1977). Increased brain dopamine and reduced glutamic acid decarboxylase and choline acetyl transferase activity in schizophrenia and related psychoses. Lancet 2 : 1157-1158.

Bitner RS, Bunnelle WH, Anderson DJ, Briggs CA, Buccafusco J, Curzon P et al (2007). Broad-spectrum efficacy across cognitive domains by alpha7 nicotinic acetylcholine receptor agonism correlates with activation of ERK1/2 and CREB phosphorylation pathways. J Neurosci 27: 10578-10587.

Biton B, Bergis OE, Galli F, Nedelec A, Lochead AW, Jegham S et al (2007). SSR180711, a novel selective alpha7 nicotinic receptor partial agonist: (1) binding and functional profile. Neuropsychopharmacology 32: 1-16. 
Blondel A, Sanger DJ, Moser PC (2000). Characterisation of the effects of nicotine in the five-choice serial reaction time task in rats: antagonist studies. Psychopharmacology 149: 293-305.

Blount P, Merlie JP (1989). Molecular basis of the two nonequivalent ligand binding sites of the muscle nicotinic acetylcholine receptor. Neuron 3: 349-357.

Bodick NC, Offen WW, Levey Al, Cutler NR, Gauthier SG, Satlin A et al (1997a). Effects of xanomeline, a selective muscarinic receptor agonist, on cognitive function and behavioral symptoms in Alzheimer disease. Arch Neurol 54: 465-473.

Bodick NC, Offen WW, Shannon HE, Satterwhite J, Lucas R, van Lier R et al (1997b). The selective muscarinic agonist xanomeline improves both the cognitive deficits and behavioral symptoms of Alzheimer disease. Alzheimer Dis Assoc Disord 11(Suppl 4): S16-S22.

Boess FG, De Vry J, Erb C, Flessner T, Hendrix M, Luithle J et al (2007). The novel alpha7 nicotinic acetylcholine receptor agonist $\mathrm{N}$-[(3R)-1-azabicyclo[2.2.2]oct-3yl]-7-[2-(methoxy)phenyl]-1-benzofuran-2-carboxamide improves working and recognition memory in rodents. J Pharmacol Exp Ther 321: 716-725.

Bolam JP, Wainer BH, Smith AD (1984). Characterization of cholinergic neurons in the rat neostriatum: a combination of choline acetyltransferase immunocytochemistry, golgi-impregnation and electron microscopy. Neuroscience 12: 711-718.

Bonner TI, Buckley NJ, Young AC, Brann MR (1987). Identification of a family of muscarinic acetylcholine receptor genes. Science 237: 527-532.

Bonner TI, Young AC, Brann MR, Buckley NJ (1988). Cloning and expression of the human and rat m5 muscarinic acetylcholine receptor genes. Neuron 1: 403-410.

Bradley SR, Lameh J, Ohrmund L, Son T, Bajpai A, Nguyen D et al (2010). AC260584, an orally bioavailable $M(1)$ muscarinic receptor allosteric agonist, improves cognitive performance in an animal model. Neuropharmacology 58: 365-373.

Brady AE, Jones CK, Bridges TM, Kennedy JP, Thompson AD, Heiman JU et al (2008). Centrally active allosteric potentiators of the M4 muscarinic acetylcholine receptor reverse amphetamine-induced hyperlocomotor activity in rats. J Pharmacol Exp Ther 327: 941-953.

Breese CR, Lee MJ, Adams CE, Sullivan B, Logel J, Gillen KM et al (2000). Abnormal regulation of high affinity nicotinic receptors in subjects with schizophrenia. Neuropsychopharmacology 23: 351-364.

Breese CR, Marks MJ, Logel J, Adams CE, Sullivan B, Collins AC et al (1997). Effect of smoking history on $[3 \mathrm{H}]$ ]nicotine binding in human postmortem brain. $J$ Pharmacol Exp Ther 282: 7-13.

Bridges TM, Kennedy JP, Hopkins CR, Conn PJ, Lindsley CW (2010). Heterobiaryl and heterobiaryl ether derived M5 positive allosteric modulators. Bioorg Med Chem Lett 20: 5617-5622.

Bridges TM, Marlo JE, Niswender CM, Jones CK, Jadhav SB, Gentry PR et al (2009). Discovery of the first highly M5-preferring muscarinic acetylcholine receptor ligand, an M5 positive allosteric modulator derived from a series of 5-trifluoromethoxy N-benzyl isatins. J Med Chem 52: 3445-3448.

Briggs CA, Anderson DJ, Brioni JD, Buccafusco JJ, Buckley MJ, Campbell JE et al (1997). Functional characterization of the novel neuronal nicotinic acetylcholine receptor ligand GTS-21 in vitro and in vivo. Pharmacol Biochem Behav 57: 231-241.

Bruno G, Mohr E, Gillespie M, Fedio P, Chase TN (1986). Muscarinic agonist therapy of Alzheimer's disease. A clinical trial of RS-86. Arch Neurol 43: 659-661.

Buccafusco JJ, Beach JW, Terry Jr AV (2009). Desensitization of nicotinic acetylcholine receptors as a strategy for drug development. J Pharmacol Exp Ther 328: 364-370.

Buccafusco JJ, Jackson WJ (1991). Beneficial effects of nicotine administered prior to a delayed matching-to-sample task in young and aged monkeys. Neurobiol Aging 12: 233-238.

Buccafusco JJ, Jackson WJ, Terry Jr AV, Marsh KC, Decker MW, Arneric SP (1995). Improvement in performance of a delayed matching-to-sample task by monkeys following ABT-418: a novel cholinergic channel activator for memory enhancement. Psychopharmacology 120: 256-266.

Buccafusco JJ, Terry Jr AV (2009). A reversible model of the cognitive impairment associated with schizophrenia in monkeys: potential therapeutic effects of two nicotinic acetylcholine receptor agonists. Biochem Pharmacol 78: 852-862.

Buccafusco JJ, Terry Jr AV, Decker MW, Gopalakrishnan M (2007). Profile of nicotinic acetylcholine receptor agonists ABT-594 and A-582941, with differential subtype selectivity, on delayed matching accuracy by young monkeys. Biochem Pharmacol 74: 1202-1211

Buchanan KA, Petrovic MM, Chamberlain SE, Marrion NV, Mellor JR (2010). Facilitation of long-term potentiation by muscarinic $M(1)$ receptors is mediated by inhibition of SK channels. Neuron 68: 948-963.

Bustillo JR, Lauriello J, Rowland LM, Thomson LM, Petropoulos H, Hammond R et al (2002). Longitudinal follow-up of neurochemical changes during the first year of antipsychotic treatment in schizophrenia patients with minimal previous medication exposure. Schizophr Res 58: 313-321.

Bymaster FP, Heath I, Hendrix JC, Shannon HE (1993). Comparative behavioral and neurochemical activities of cholinergic antagonists in rats. J Pharmacol Exp Ther 267: 16-24.

Byun N, Lawson K, Gore JC, Conn PJ, Jones CK (2011). Antipsychotic-like profile and reversal of cognitive impairment with the positive allosteric modular of the M4 muscarinic acetylcholine receptor VU0152100. Abstracts of the 13th International Congress on Schizophrenia Research (ICOSR). Schizophr Bull Suppl 1: 1-342.

Campo-Arias A, Díaz-Martínez LA, Rueda-Jaimes GE, Rueda-Sánchez M, Farelo-Palacín D, Diaz FJ et al (2006). Smoking is associated with schizophrenia, but not with mood disorders, within a population with low smoking rates: a matched case-control study in Bucaramanga, Colombia. Schizophr Res 83: 269-276.

Carbone AL, Moroni M, Groot-Kormelink PJ, Bermudez I (2009). Pentameric concatenated (alpha4)(2)(beta2)(3) and (alpha4)(3)(beta2)(2) nicotinic acetylcholine receptors: subunit arrangement determines functional expression. $\mathrm{Br} J$ Pharmacol 156: 970-981.

Carey GJ, Billard W, Binch 3rd H, Cohen-Williams M, Crosby G, Grzelak M et al (2001). SCH 57790, a selective muscarinic M(2) receptor antagonist, releases acetylcholine and produces cognitive enhancement in laboratory animals. Eur $J$ Pharmacol 431: 189-200.

Carlsson A (1977). Does dopamine play a role in schizophrenia? Psychol Med 7: 583-597.

Castner SA, Smagin GN, Piser TM, Wang Y, Smith JS, Christian EP et al (2011). Immediate and sustained improvements in working memory after selective stimulation of $\alpha 7$ nicotinic acetylcholine receptors. Biol Psychiatry 69: 12-18.

Chambon C, Wegener N, Gravius A, Danysz W (2011). A new automated method to assess the rat recognition memory: validation of the method. Behav Brain Res 222: 151-157.

Chan WK, Wong PT, Sheu FS (2007). Frontal cortical alpha7 and alpha4beta2 nicotinic acetylcholine receptors in working and reference memory. Neurophar macology 52: 1641-1649.

Chan WY, McKinzie DL, Bose S, Mitchell SN, Witkin JM, Thompson RC et al (2008). Allosteric modulation of the muscarinic M4 receptor as an approach to treating schizophrenia. Proc Natl Acad Sci USA 105: 10978-10983.

Changeux JP, Devillers-Thiéry A, Chemouilli $P$ (1984). Acetylcholine receptor: an allosteric protein. Science 225: 1335-1345.

Christopoulos A, Mitchelson F (1997). Application of an allosteric ternary complex model to the technique of pharmacological resultant analysis. I Pharm Pharmacol 49: 781-786.

Conn PJ, Christopoulos A, Lindsley CW (2009). Allosteric modulators of GPCRs: a novel approach for the treatment of CNS disorders. Nat Rev Drug Discov 8: 41-54.

Conti-Tronconi BM, Hunkapiller MW, Lindstrom JM, Raftery A (1982). Subunit structure of the acetylcholine receptor from electrophorus electricus. Proc Natl Acad Sci USA 79: 6489-6493.

Corriveau RA, Berg DK (1993). Coexpression of multiple acetylcholine receptor genes in neurons: quantification of transcripts during development. $J$ Neurosci 13: 2662-2671.

Costa E, Auta J, Caruncho H, Guidotti A, Impagnatiello F, Pesold C et al (1995). A search for a new anticonvulsant and anxiolytic benzodiazepine devoid of side effects and tolerance liability. Adv Biochem Psychopharmacol 48: 75-92.

Court J, Spurden D, Lloyd S, McKeith I, Ballard C, Cairns N et al (1999). Neuronal nicotinic receptors in dementia with Lewy bodies and schizophrenia: alphabungarotoxin and nicotine binding in the thalamus. I Neurochem 73 1590-1597.

Court JA, Lloyd S, Thomas N, Piggott MA, Marshall EF, Morris CM et al (1998). Dopamine and nicotinic receptor binding and the levels of dopamine and homovanillic acid in human brain related to tobacco use. Neuroscience 87: 63-78.

Crook JM, Dean B, Pavey G, Copolov D (1999). The binding of [3H]AF-DX 384 is reduced in the caudate-putamen of subjects with schizophrenia. Life Sci 64: 1761-1771.

Crook JM, Tomaskovic-Crook E, Copolov DL, Dean B (2000). Decreased muscarinic receptor binding in subjects with schizophrenia: a study of the human hippocampal formation. Biol Psychiatry 48: 381-388.

Crook JM, Tomaskovic-Crook E, Copolov DL, Dean B (2001). Low muscarinic receptor binding in prefrontal cortex from subjects with schizophrenia: a study of Brodmann's areas 8, 9, 10, and 46 and the effects of neuroleptic drug treatment. Am J Psychiatry 158: 918-925.

Dajas-Bailador FA, Mogg AJ, Wonnacott S (2002). Intracellular Ca2+ signals evoked by stimulation of nicotinic acetylcholine receptors in $\mathrm{SH}-\mathrm{SY} 5 \mathrm{Y}$ cells: contribution of voltage-operated Ca2+ channels and Ca2+ stores. J Neurochem 81: 606-614. 
Dean B, Crook JM, Opeskin K, Hill C, Keks N, Copolov DL (1996). The density of muscarinic $\mathrm{M} 1$ receptors is decreased in the caudate-putamen of subjects with schizophrenia. Mol Psychiatry 1: 54-58.

Dean B, McLeod M, Keriakous D, McKenzie J, Scarr E (2002). Decreased muscarinic(1) receptors in the dorsolateral prefrontal cortex of subjects with schizophrenia. Mol Psychiatry 7: 1083-1091.

Decker MW, Bannon AW, Curzon P, Gunther KL, Brioni JD, Holladay MW et al (1997). ABT-089 [2-methyl-3-(2-(S)-pyrrolidinylmethoxy)pyridine dihydrochloride]: II. A novel cholinergic channel modulator with effects on cognitive performance in rats and monkeys. J Pharmacol Exp Ther 283: 247-258.

Decker MW, Brioni JD, Sullivan JP, Buckley MJ, Radek RJ, Raszkiewicz JL et al (1994a). (S)-3-methyl-5-(1-methyl-2-pyrrolidinyl)isoxazole (ABT 418): a novel cholinergic ligand with cognition-enhancing and anxiolytic activities: II. In vivo characterization. J Pharmacol Exp Ther 270: 319-328.

Decker MW, Curzon P, Brioni JD, Arnerić SP (1994b). Effects of ABT-418, a novel cholinergic channel ligand, on place learning in septal-lesioned rats. Eur $J$ Pharmacol 261: 217-222.

Decker MW, Majchrzak MJ (1992). Effects of systemic and intracerebroventricular administration of mecamylamine, a nicotinic cholinergic antagonist, on spatial memory in rats. Psychopharmacology 107: 530-534

De Leon J, Dadvand M, Canuso C, White AO, Stanilla JK, Simpson GM (1995). Schizophrenia and smoking: an epidemiological survey in astate hospital. Am J Psychiatry 152: 453-455.

De Leon J, Diaz FJ, Rogers T, Browne D, Dinsmore L (2002). Initiation of daily smoking and nicotine dependence in schizophrenia and mood disorders. Schizophr Res 56: 47-54.

De Luca V, Voineskos S, Wong G, Kennedy JL (2006). Genetic interaction between $\alpha 4$ and $\beta 2$ of high affinity nicotinic receptor: analysis in schizophrenia. Exp Brain Res 174: 292-296.

De Luca V, Wang H, Squassina A, Wong GW, Yeomans J, Kennedy JL (2004). Linkage of M5 muscarinic and alpha7-nicotinic receptor genes on $15 q 13$ to schizophrenia. Neuropsychobiology 50: 124-127.

Deng C, Huang XF (2005). Decreased density of muscarinic receptors in the superior temporal gyrus in schizophrenia. J Neurosci Res 81: 883-890.

Digby GJ, Conn PJ, Lindsley CW (2010). Orthosteric- and allosteric-induced liganddirected trafficking at GPCRs. Curr Opin Drug Discov Dev 13: 587-594.

Domer FR, Schueler FW (1960). Investigations of the amnesic properties of scopolamine and related compounds. Arch Int Pharmacodyn Ther 127: 449-458.

Domino EF, Mohrman ME, Wilson AE, Haarstad VB (1973). Acetylseco hemicholinium-3, a new choline acetyltransferase inhibitor useful in neuropharmacological studies. Neuropharmacology 12: 549-561.

Dunbar G, Kuchibhatla R, Lee G (2011). A randomized double-blind study comparing 25 and $50 \mathrm{mg}$ TC-1734 (AZD3480) with placebo, in order subjects with age-associated memory impairment. J Psychopharmacol 25: 1020-1029.

Dutar P, Nicoll RA (1988). Classification of muscarinic responses in hippocampus in terms of receptor subtypes and second-messenger systems: electrophysiological studies in vitro. J Neurosci 8: 4214-4224.

Edelstein P, Schultz JR, Hirschowitz J, Kanter DR, Garver DL (1981). Physostigmine and lithium in the schizophrenias. Am J Psychiatry 138: 1078-1081.

Ehlert FJ, Roeske WR, Gee KW, Yamamura HI (1983). An allosteric model for benzodiazepine receptor function. Biochem Pharmacol 32: 2375-2383.

Elrod K, Buccafusco JJ, Jackson WJ (1988). Nicotine enhances delayed matchingto-sample performance by primates. Life Sci 43: 277-287.

Erwin RJ, Turetsky BI, Moberg P, Gur RC, Gur RE (1998). P50 abnormalities in schizophrenia: relationship to clinical and neuropsychological indices of attention. Schizophr Res 33: 157-167.

Espada S, Rojo Al, Salinas M, Cuadrado A (2009). The muscarinic M1 receptor activates Nrf2 through a signaling cascade that involves protein kinase $\mathrm{C}$ and inhibition of GSK-3beta: connecting neurotransmission with neuroprotection. J Neurochem 110: 1107-1119.

Fabian-Fine R, Skehel P, Errington ML, Davies HA, Sher E, Stewart MG et al (2001). Ultrastructural distribution of the alpha7 nicotinic acetylcholine receptor subunit in rat hippocampus. J Neurosci 21: 7993-8003.

Faghih R, Gopalakrishnan SM, Gronlien JH, Malysz J, Briggs CA, Wetterstrand C et al (2009). Discovery of 4-(5-(4-chlorophenyl)-2-methyl-3-propionyl-1H-pyrrol1-yl)benzenesulfonamide (A-867744) as a novel positive allosteric modulator of the alpha7 nicotinic acetylcholine receptor. J Med Chem 52: 3377-3384.

Felder CC (1995). Muscarinic acetylcholine receptors: signal transduction through multiple effectors. FASEB J 9: 619-625.

Feldman HH, Ferris S, Winblad B, Sfikas N, Mancione L, He Y et al (2007). Effect of rivastigmine on delay to diagnosis of Alzheimer's disease from mild cognitive impairment: the InDDEx study. Lancet Neurol 6: 501-512.

Fenster CP, Rains MF, Noerager B, Quick MW, Lester RA (1997). Influence of subunit composition on desensitization of neuronal acetylcholine receptors at low concentrations of nicotine. J Neurosci 17: 5747-5759.
Feuerbach D, Lingenhoehl K, Olpe HR, Vassout A, Gentsch C, Chaperon F et al (2009). The selective nicotinic acetylcholine receptor alpha7 agonist JN403 is active in animal models of cognition, sensory gating, epilepsy and pain. Neuropharmacology 56: 254-263.

File SE (1985). Tolerance to the behavioral actions of benzodiazepines. Neurosci Biobehav Rev 9: 113-121.

Fink-Jensen A, Fedorova I, Wörtwein G, Woldbye DP, Rasmussen T, Thomsen M et al (2003). Role for M5 muscarinic acetylcholine receptors in cocaine addiction. J Neurosci Res 74: 91-96.

Forette F, Anand R, Gharabawi G (1999). A phase II study in patients with Alzheimer's disease to assess the preliminary efficacy and maximum tolerated dose of rivastigmine (Exelon). Eur J Neurol 6: 423-429.

Freedman R, Coon H, Myles-Worsley M, Orr-Urtreger A, Olincy A, Davis A et al (1997). Linkage of a neurophysiological deficit in schizophrenia to a chromosome 15 locus. Proc Natl Acad Sci USA 94: 587-592.

Freedman R, Hall M, Adler LE, Leonard S (1995). Evidence in postmortem brain tissue for decreased numbers of hippocampal nicotinic receptors in schizophrenia. Biol Psychiatry 38: 22-33.

Freedman R, Leonard S, Gault JM, Hopkins J, Cloninger CR, Kaufmann CA et al (2001). Linkage disequilibrium for schizophrenia at the chromosome 15q13-14 locus of the alpha7-nicotinic acetylcholine receptor subunit gene (CHRNA7). Am J Med Genet 105: 20-22.

Freedman R, Olincy A, Buchanan RW, Harris JG, Gold JM, Johnson L et al (2008). Initial phase 2 trial of a nicotinic agonist in schizophrenia. Am J Psychiatry 165: 1040-1047.

Garver DL, Bissette G, Yao JK, Nemeroff CB (1991). Relation of CSF neurotensin concentrations to symptoms and drug response of psychotic patients. Am J Psychiatry 148: 484-488.

George TP, Termine A, Sacco KA, Allen TM, Reutenauer E, Vessicchio JC et al (2006). A preliminary study of the effects of cigarette smoking on prepulse inhibition in schizophrenia: involvement of nicotinic receptor mechanisms. Schizophr Res 87: 307-315.

Gerber DJ, Sotnikova TD, Gainetdinov RR, Huang SY, Caron MG, Tonegawa S (2001). Hyperactivity, elevated dopaminergic transmission, and response to amphetamine in Ml muscarinic acetylcholine receptor-deficient mice. Proc Natl Acad Sci USA 98: 15312-15317.

Gerlach J, Thorsen K, Fog R (1975). Extrapyramidal reactions and amine metabolites in cerebrospinal fluid during haloperidol and clozapine treatment of schizophrenic patients. Psychopharmacologia 40: 341-350.

Gomeza J, Shannon H, Kostenis E, Felder C, Zhang L, Brodkin J et al (1999b). Pronounced pharmacologic deficits in M2 muscarinic acetylcholine receptor knockout mice. Proc Natl Acad Sci USA 96: 1692-1697.

Gomeza J, Zhang L, Kostenis E, Felder C, Bymaster F, Brodkin J et al (1999a). Enhancement of D1 dopamine receptor-mediated locomotor stimulation in $\mathrm{M}(4)$ muscarinic acetylcholine receptor knockout mice. Proc Natl Acad Sci USA 96: 10483-10488

Gopalakrishnan M, Molinari EJ, Sullivan JP (1997). Regulation of human $\alpha 4 \beta 2$ neuronal nicotinic acetylcholine receptors by cholinergic channel ligands and second messenger pathways. Mol Pharmacol 52: 524-534.

Gotti C, Clementi F (2004). Neuronal nicotinic receptors: from structure to pathology. Prog Neurobiol 74: 363-396.

Green MF, Kern RS, Heaton RK (2004). Longitudinal studies of cognition and functional outcome in schizophrenia: implications for MATRICS. Schizophr Res 72: $41-51$.

Griffith JM, O'Neill JE, Petty F, Garver D, Young D, Freedman R (1998). Nicotinic receptor desensitization and sensory gating deficits in schizophrenia. Biol Psychiatry 44: 98-106.

Gronlien JH, Håkerud M, Ween H, Thorin-Hagene K, Briggs CA, Gopalakrishnan M et al (2007). Distinct profiles of alpha7 nAChR positive allosteric modulation revealed by structurally diverse chemotypes. Mol Pharmacol 72: 715-724.

Grottick AJ, Haman M, Wyler R, Higgins GA (2003). Reversal of a vigilance decrement in the aged rat by subtype-selective nicotinic ligands. Neuropsychopharmacology 28: 880-887.

Grottick AJ, Higgins GA (2000). Effect of subtype selective nicotinic compounds on attention as assessed by the five-choice serial reaction time task. Behav Brain Res 117: 197-208.

Grottick AJ, Trube G, Corrigall WA, Huwyler J, Malherbe P, Wyler R et al (2000). Evidence that nicotinic alpha(7) receptors are not involved in the hyperlocomotor and rewarding effects of nicotine. J Pharmacol Exp Ther 294: 1112-1119.

Guan ZZ, Zhang X, Blennow K, Nordberg A (1999). Decreased protein level of nicotinic receptor alpha7 subunit in the frontal cortex from schizophrenic brain. Neuroreport 10: 1779-1782.

Hahn B, Sharples CG, Wonnacott S, Shoaib M, Stolerman IP (2003). Attentional effects of nicotinic agonists in rats. Neuropharmacology 44: 1054-1067. 
Hamborg-Petersen B, Nielsen MM, Thordal C (1984). Toxic effect of scopolamine eye drops in children. Acta Ophthalmol 62: 485-488.

Hansen HH, Timmermann DB, Peters D, Walters C, Damaj MI, Mikkelsen JD (2007). Alpha-7 nicotinic acetylcholine receptor agonists selectively activate limbic regions of the rat forebrain: an effect similar to antipsychotics. J Neurosci Res 85: 1810-1818.

Harington M, Kincaid-Smith P (1958). Psychosis and tremor due to mecamylamine. Lancet 271: 499-501.

Harris JG, Kongs S, Allensworth D, Martin L, Tregellas J, Sullivan B et al (2004). Effects of nicotine on cognitive deficits in schizophrenia. Neuropsychopharmacology 29: 1378-1385.

Harvey AL, Dryden WF (1974). Studies on the pharmacology of skeletal muscle in culture: site of action of nicotinic agonists. Eur J Pharmacol 28: 131-134.

Hashimoto K, Ishima T, Fujita Y, Matsuo M, Kobashi T, Takahagi M et al (2008). Phencyclidine-induced cognitive deficits in mice are improved by subsequent subchronic administration of the novel selective alpha7 nicotinic receptor agonist SSR180711. Biol Psychiatry 63: 92-97.

Hasselmo ME, Sarter M (2010). Modes and models of forebrain cholinergic neuromodulation of cognition. Neuropsychopharmacology 36: 52-73.

Hauser TA, Kucinski A, Jordan KG, Gatto GJ, Wersinger SR, Hesse RA et al (2009). TC-5619: an alpha7 neuronal nicotinic receptor-selective agonist that demonstrates efficacy in animal models of the positive and negative symptoms and cognitive dysfunction of schizophrenia. Biochem Pharmacol 78: 803-812.

Heinrich JN, Butera JA, Carrick T, Kramer A, Kowal D, Lock T et al (2009). Pharmacological comparison of muscarinic ligands: historical vs more recent muscarinic M1-preferring receptor agonists. Eur J Pharmacol 605: 53-56.

Hersch SM, Gutekunst CA, Rees HD, Heilman CJ, Levey Al (1994). Distribution of m1-m4 muscarinic receptor proteins in the rat striatum: light and electron microscopic immunocytochemistry using subtype-specific antibodies. $J$ Neurosci 14: 3351-3363

Howes OD, Kapur S (2009). The dopamine hypothesis of schizophrenia: version III- the final common pathway. Schizophr Bull 35: 549-562.

Hu M, Gopalakrishnan M, Li J (2009). Positive allosteric modulation of alpha7 neuronal nicotinic acetylcholine receptors: lack of cytotoxicity in PC12 cells and rat primary cortical neurons. Br J Pharmacol 158: 1857-1864.

Hurst RS, Hajos M, Raggenbass M, Wall TM, Higdon NR, Lawson JA et al (2005). A novel positive allosteric modulator of the alpha7 neuronal nicotinic acetylcholine receptor: in vitro and in vivo characterization. J Neurosci 25: 4396-4405.

Idänpään-Heikkilä J, Alhava E, Olkinuora M, Palva I (1975). Clozapine and agranulocytosis. Lancet [Letter] 306: 611.

Ince E, Ciliax BJ, Levey Al (1997). Differential expression of D1 and D2 dopamine and $\mathrm{m} 4$ muscarinic acetylcholine receptor proteins in identified striatonigral neurons. Synapse 27: 357-366.

Ingram JR, Rhodes J, Evans BK, Thomas GA (2005). Preliminary observations of oral nicotine therapy for inflammatory bowel disease: an open-label phase I-II study of tolerance. Inflamm Bowel Dis 11: 1092-1096.

Izzo AA, Mascolo N, Di Carlo G, Capasso F (1999). Ascending neural pathways in the isolated guinea-pig ileum: effect of muscarinic M1, M2 and M3 cholinergic antagonists. Neuroscience 91: 1575-1580.

Jacobson MA, Kreatsoulas C, Pascarella DM, O'Brien JA, Sur C (2010). The M1 muscarinic receptor allosteric agonists AC-42 and 1-[1'-(2-methylbenzyl)-1,4'bipiperidin-4-yl]-1,3-dihydro-2H-benzimidazol-2-one bind to a unique site distinct from the acetylcholine orthosteric site. Mol Pharmacol 78: 648-657.

Janowsky DS, el-Yousef MK, Davis JM, Sekerke HJ (1973). Antagonistic effects of physostigmine and methylphenidate in man. Am J Psychiatry 130: 1370137-1370136

Jentsch JD, Roth RH (1999). The neuropsychopharmacology of phencyclidine: from NMDA receptor hypofunction to the dopamine hypothesis of schizophrenia. Neuropsychopharmacology 20: 201-225.

Jeon J, Dencker D, Wörtwein G, Woldbye DP, Cui Y, Davis AA et al (2010). A subpopulation of neuronal M4 muscarinic acetylcholine receptors plays a critical role in modulating dopamine-dependent behaviors. J Neurosci 30: 2396-2405.

Ji D, Dani JA (2000). Inhibition and disinhibition of pyramidal neurons by activation of nicotinic receptors on hippocampal interneurons. J Neurophysiol 83: 2682-2690.

Ji D, Lape R, Dani JA (2001). Timing and location of nicotinic activity enhances or depresses hippocampal synaptic plasticity. Neuron 31: 131-141.

Jo J, Son GH, Winters BL, Kim MJ, Whitcomb DJ, Dickinson BA et al (2010). Muscarinic receptors induce LTD of NMDAR EPSCs via a mechanism involving hippocalcin, AP2 and PSD-95. Nat Neurosci 13: 1216-1224.

Jones CK, Brady AE, Davis AA, Xiang Z, Bubser M, Tantawy MN et al (2008). Novel selective allosteric activator of the M1 muscarinic acetylcholine receptor regulates amyloid processing and produces antipsychotic-like activity in rats. J Neurosci 28: 10422-10433.
Jones CK, Eberle EL, Shaw DB, McKinzie DL, Shannon HE (2005). Pharmacologic interactions between the muscarinic cholinergic and dopaminergic systems in the modulation of prepulse inhibition in rats. $J$ Pharmacol Exp Ther 312 1055-1063.

Jubelt LE, Barr RS, Goff DC, Logvinenko T, Weiss AP, Evins AE (2008). Effects of transdermal nicotine on episodic memory in non-smokers with and without schizophrenia. Psychopharmacology 199: 89-98.

Kaplan MJ, Lazoff M, Kelly K, Lukin R, Garver DL (1990). Enlargement of cerebral third ventricle in psychotic patients with delayed response to neuroleptics. Biol Psychiatry 27: 205-214.

Kapur S, Arenovich T, Agid O, Zipurski R, Lindborg S, Jones B (2005). Evidence for onset of antipsychotic effects within the first $24 \mathrm{~h}$ of treatment. Am J Psychiatry 162: 939-946.

Karson CN, Casanova MF, Kleinman JE, Griffin WS (1993). Choline acetyltransferase in schizophrenia. Am J Psychiatry 50: 454-459.

Karson CN, Mrak RE, Husain MM, Griffin WS (1996). Decreased mesopontine choline acetyltransferase levels in schizophrenia. Correlations with cognitive functions. Mol Chem Neuropathol 29: 181-191.

Katerina Z, Andrew K, Filomena M, Xu-Feng $H$ (2004). Investigation of $\mathrm{m} 1 / \mathrm{m} 4$ muscarinic receptors in the anterior cingulate cortex in schizophrenia, bipolar disorder, and major depression disorder. Neuropsychopharmacology 29: 619-625.

Keefe RS, Sweeney JA, Gu H, Hamer RM, Perkins DO, McEvoy JP et al (2007). Effects of olanzapine, quetiapine, and risperidone on neurocognitive function in early psychosis: a randomized, double-blind 52-week comparison. Am J Psychiatry 164: 1061-1071.

Kenakin T (2008). Functional selectivity in GPCR modulator screening. Comb Chem High Throughput Screen 11: 337-343.

Kenney JW, Wilkinson DS, Gould TJ (2010). The enhancement of contextual fear conditioning by ABT-418. Behav Pharmacol 21: 246-249.

Kimura H, McGeer PL, Peng F, McGeer EG (1980). Choline acetyltransferasecontaining neurons in rodent brain demonstrated by immunohistochemistry. Science 208: 1057-1059.

Kirrane RM, Mitropoulou V, Nunn M, Silverman J, Siever LJ (2001). Physostigmine and cognition in schizotypal personality disorder. Schizophr Res 48: 1-5.

Kishi T, Ikeda M, Kitajima T, Yamanouchi Y, Kinoshita Y, Kawashima $\mathrm{K}$ et al (2008). Genetic association analysis of tagging SNPs in alpha4 and beta2 subunits of neuronal nicotinic acetylcholine receptor genes (CHRNA4 and CHRNB2) with schizophrenia in the Japanese population. J Neural Transm 115: 1457-1461.

Kitagawa H, Takenouchi T, Azuma R, Wesnes K, Kramer W, Clody D et al (2003). Safety, pharmacokinetics, and effects on cognitive function of multiple doses of GTS-21 in healthy, male volunteers. Neuropsychopharmacology 28: 542-551.

Klein C, Andersen B (1991). On the influence of smoking upon smooth pursuit eye movements of schizophrenics and normal controls. J Psychophysiology $\mathbf{5}$ 361-369.

Kozak R, Bruno JP, Sarter M (2006). Augmented prefrontal acetylcholine release during challenged attentional performance. Cereb Cortex 16: 9-17.

Krystal JH, Anand A, Moghaddam B (2002). Effects of NMDA receptor antagonists: implications for the pathophysiology of schizophrenia. Arch Gen Psychiatry 59: 663-664

Kuehn BM (2008). FDA warns of adverse events linked to smoking cessation drug and antiepileptics. JAMA 299: 1121-1122.

Lagostena C, Trocme-Thibierge P, Morain E, Cherubini E (2008). The partial alpha7 nicotine acetylcholine receptor agonist S 24795 enhances long-term potentiation at CA3-CA1 synapses in the adult mouse hippocampus. Neuropharmacology 54: 676-685.

Langmead CJ, Austin NE, Branch CL, Brown JT, Buchanan KA, Davies CH et al (2008). Characterization of a CNS penetrant, selective M1 muscarinic receptor agonist, 77-LH-28-1. Br J Pharmacol 54: 1104-1115.

Langmead CJ, Fry VA, Forbes IT, Branch CL, Christopoulos A, Wood MD et al (2006). Probing the molecular mechanism of interaction between 4-n-butyl-1[4-(2-methylphenyl)-4-oxo-1-butyl]-piperidine (AC-42) and the muscarinic $\mathrm{M} 1$ receptor: direct pharmacological evidence that AC-42 is an allosteric agonist. Mol Pharmacol 69: 236-246.

Lazareno S, Doležal V, Popham A, Birdsall NJM (2004). Thiochrome enhances acetylcholine affinity at muscarinic M4 receptors: receptor subtype selectivity via cooperativity rather than affinity. J Pharmacol Exp Ther 65: 257-266.

Leach K, Loiacono RE, Felder CC, McKinzie DL, Mogg A, Shaw DB et al (2010). Molecular mechanisms of action and in vivo validation of an M4 muscarinic acetylcholine receptor allosteric modulator with potential antipsychotic properties. Neuropsychopharmacology 35: 855-869.

Lebois EP, Bridges TM, Lewis LM, Dawson ES, Kane AS, Xiang Z et al (2010). Discovery and characterization of novel subtype-selective allosteric agonists for the investigation of M1 receptor function in the central nervous system. ACS Chem Neurosci 1: 104-121. 
Leonard S, Gault J, Adams C, Breese CR, Rollins Y, Adler LE et al (1998). Nicotinic receptors, smoking and schizophrenia. Restor Neurol Neurosci 12: 195-201.

Leonard S, Gault J, Hopkins J, Logel J, Vianzon R, Short M et al (2002). Association of promoter variants in the alpha7 nicotinic acetylcholine receptor subunit gene with an inhibitory deficit found in schizophrenia. Arch Gen Psychiatry 59: 1085-1096.

Leucht S, Busch R, Hamann J, Kissling W, Kane JM (2005). Early-onset hypothesis of antipsychotic drug action: a hypothesis tested, confirmed and extended. Biol Psychiatry 57: 1543-1549.

Levey Al, Edmunds SM, Heilman CJ, Desmond TJ, Frey KA (1994). Localization of muscarinic $\mathrm{m} 3$ receptor protein and $\mathrm{M} 3$ receptor binding in rat brain. Neuroscience 63: 207-221.

Levey Al, Edmunds SM, Hersch SM, Wiley RG, Heilman CJ (1995a). A light and electron microscopic study of $\mathrm{m} 2$ muscarinic acetylcholine receptor in the basal forebrain of the rat. J Comp Neurol 351: 339-356.

Levey Al, Edmunds SM, Koliatsos V, Wiley RG, Heilman CJ (1995b). Expression of ml-m4 muscarinic acetylcholine receptor proteins in rat hippocampus and regulation by cholinergic innervation. J Neurosci 15: 4077-4092.

Levey Al, Kitt CA, Simonds WF, Price DL, Brann MR (1991). Identification and localization of muscarinic acetylcholine receptor proteins in brain with subtypespecific antibodies. J Neurosci 11: 3218-3226.

Levin ED (1992). Nicotinic systems and cognitive function. Psychopharmacology 108: $417-431$.

Levin ED (2002). Nicotinic receptor subtypes and cognitive function. J Neurobio/ 53 : 633-640.

Levin ED, Bettegowda C, Blosser J, Gordon J (1999). AR-R17779, and alpha7 nicotinic agonist, improves learning and memory in rats. Behave Pharmacol 10: 675-680.

Levin ED, Briggs SJ, Christopher NC, Rose JE (1992). Persistence of chronic nicotine-induced cognitive facilitation. Behav Neural Biol 58: 152-158.

Levin ED, Christopher NC, Briggs SJ (1997). Chronic nicotinic agonist and antagonist effects on T-maze alternation. Physiol Behav 61: 863-866.

Levin ED, Conners CK, Silva D, Hinton SC, Meck WH, March J et al (1998). Transdermal nicotine effects on attention. Psychopharmacology (Berl) 140: 135-141.

Levin ED, McClernon FJ, Rezvani AH (2006). Nicotinic effects on cognitive function: behavioral characterization, pharmacological specification, and anatomic localization. Psychopharmacology 184: 523-539.

Lewis DA, Moghaddam B (2006). Cognitive dysfunction in schizophrenia: convergence of gamma-aminobutyric acid and glutamate alterations. Arch Neurol 63: 1372-1376.

Li X, Rainnie DG, McCarley RW, Greene RW (1998). Presynaptic nicotinic receptors facilitate monoaminergic transmission. J. Neurosci 18: 1904-1912.

Li Z, Bonhaus DW, Huang M, Prus AJ, Dai J, Meltzer HY (2007). AC260584 (4-[3(4-butylpiperidin-1-yl)-propyl]-7-fluoro-4H-benzo[1,4]oxazin-3-one), a selective muscarinic M1 receptor agonist, increases acetylcholine and dopamine release in rat medial prefrontal cortex and hippocampus. Eur J Pharmacol 572: 129-137.

Liao CF, Themmen APN, Joho R, Barberis C, Birnbaumer M, Birnbaumer L (1989). Molecular cloning and expression of a fifth muscarinic acetylcholine receptor. J Biol Chem 264: 7328-7337.

Liao DL, Hong CJ, Chen HM, Chen YE, Lee SM, Chang CY et al (2003). Association of muscarinic $\mathrm{m} 1$ receptor genetic polymorphisms with psychiatric symptoms and cognitive function in schizophrenic patients. Neuropsychobiology 48: 72-76.

Lieberman JA, Tollefson G, Tohen M, Green Al, Gur RE, Kahn R, et al, HGDH Study Group (2003). Comparative efficacy and safety of atypical and conventional antipsychotic drugs in first-episode psychosis: a randomized, double-blind trial of olanzapine vs haloperidol. Am J Psychiatry 160: 1396-1404.

Lin NH, Gunn DE, Ryther KB, Garvey DS, Donnelly-Roberts DL, Decker MW et al (1997). Structure-activity studies on 2-methyl-3-(2(S)-pyrrolidinylmethoxy) pyridine (ABT-089): an orally bioavailable 3-pyridyl ether nicotinic acetylcholine receptor ligand with cognition-enhancing properties. J Med Chem 40: 385-390.

Lohr JB, Flynn K (1992). Smoking and schizophrenia. Schizophr Res 8: 93-102.

Luo S, Kulak JM, Cartier GE, Jacobsen RB, Yoshikami D, Olivera BM et al (1998). Alpha-conotoxin AulB selectively blocks alpha3 beta4 nicotinic acetylcholine receptors and nicotine-evoked norepinephrine release. J Neurosci 18: 8571-8579.

Ma L, Seager MA, Wittmann M, Jacobson M, Bickel D, Burno M et al (2009). Selective activation of the M1 muscarinic acetylcholine receptor achieved by allosteric potentiation. Proc Natl Acad Sci USA 106: 15950-15955.

Malysz J, Grønlien JH, Timmermann DB, Håkerud M, Thorin-Hagene K, Ween H et al (2009). Evaluation of alpha7 nicotinic acetylcholine receptor agonists and positive allosteric modulators using the parallel oocyte electrophysiology test station. Assay Drug Dev Technol 7: 374-390.
Mancama D, Arranz MJ, Landau S, Kerwin R (2003). Reduced expression of the muscarinic 1 receptor cortical subtype in schizophrenia. Am J Med Genet B Neuropsychiatr Genet 119B: 2-6.

Mann EO, Greenfield SA (2003). Novel modulatory mechanisms revealed by the sustained application of nicotine in the guinea-pig hippocampus in vitro. J Physiol 551: 539-550.

Mansvelder HD, Keath JR, McGehee DS (2002). Synaptic mechanisms underlie nicotine-induced excitability of brain reward areas. Neuron 33: 905-919.

Mansvelder HD, McGehee DS (2000). Long-term potentiation of excitatory inputs to brain reward areas by nicotine. Neuron 27: 349-357.

Marino MJ, Rouse ST, Levey Al, Potter LT, Conn PJ (1998). Activation of the genetically defined $\mathrm{m} 1$ muscarinic receptor potentiates $\mathrm{N}$-methyl-D-aspartate (NMDA) receptor currents in hippocampal pyramidal cells. Proc Natl Acad Sci USA 95: 11465-11470.

Marlo JE, Niswender CM, Days EL, Bridges TM, Xiang Y, Rodriguez AL et al (2009). Discovery and characterization of novel allosteric potentiators of M1 muscarinic receptors reveals multiple modes of activity. Mol Pharmacol 75: 577-588.

Martin-Ruiz CM, Haroutunian VH, Long P, Young AH, Davis KL, Perry EK et al (2003). Dementia rating and nicotinic receptor expression in the prefrontal cortex in schizophrenia. Biol Psychiatry 54: 1222-1233.

Marubio LM, del Mar Arroyo-Jimenez M, Cordero-Erausquin M, Léna C, Le Novère $\mathrm{N}$, de Kerchove d'Exaerde A et al (1999). Reduced antinociception in mice lacking neuronal nicotinic receptor subunits. Nature 398: 805-810.

Marutle A, Zhang X, Court J, Piggott M, Johnson M, Perry R et al (2001). Laminar distribution of nicotinic receptor subtypes in cortical regions in schizophrenia. J Chem Neuroanat 22: 115-126.

Matsuoka N, Maeda N, Ohkubo Y, Yamaguchi I (1991). Differential effects of physostigmine and pilocarpine on the spatial memory deficits produced by two septo-hippocampal deafferentations in rats. Brain Res 559: 233-240.

McDermott BE, Sautter FJ, Garver DL (1991). Heterogeneity of schizophrenia: relationship to latency of neuroleptic response. Psychiatry Res 37: 97-103.

McGeer PL, McGeer EG (1977). Possible changes in striatal and limbic cholinergic systems in schizophrenia. Arch Gen Psychiatry 34: 1319-1323.

McQuiston AR, Madison DV (1999). Nicotinic receptor activation excites distinct subtypes of interneurons in the rat hippocampus. J Neurosci 19: 2887-2896.

Mesulam MM, Mufson EJ, Wainer BH, Levey Al (1983). Central cholinergic pathways in the rat: an overview based on an alternative nomenclature (Ch1-Ch6). Neuroscience 10: 1185-1201.

Mexal S, Berger R, Logel J, Ross RG, Freedman R, Leonard S (2010). Differential regulation of alpha7 nicotinic receptor gene (CHRNA7) expression in schizophrenic smokers. J Mol Neurosci 40: 185-195.

Migeon JC, Thomas SL, Nathanson NM (1995). Differential coupling of m2 and m4 muscarinic receptors to inhibition of adenylyl cyclase by Gi alpha and G(o)alpha subunits. J Biol Chem 270: 16070-16074.

Mihalak KB, Carroll Fl, Luetje CW (2006). Varenicline is a partial agonist at alpha4beta2 and a full agonist at alpha7 neuronal nicotinic receptors. Mol Pharmacol 70: 801-805.

Miyakawa T, Yamada M, Duttaroy A, Wess J (2001). Hyperactivity and intact hippocampus-dependent learning in mice lacking the M1 muscarinic acetylcholine receptor. J Neurosci 21: 5239-5250.

Moran PM (1993). Differential effects of scopolamine and mecamylamine on working and reference memory in the rat. Pharmacol Biochem Behav 45: 533-538.

Mukhin AG, Gündisch D, Horti AG, Koren AO, Tamagnan G, Kimes AS et al (2000). 5-lodo-A-85380, an alpha4beta2 subtype-selective ligand for nicotinic acetylcholine receptors. Mol Pharmacol 57: 642-649.

Mulle C, Vidal C, Benoit P, Changeux JP (1991). Existence of different subtypes of nicotinic acetylcholine receptors in the rat habenulo-interpeduncular system. J Neurosci 11: 2588-2597.

Mullen G, Napier J, Balestra M, DeCory T, Hale G, Macor J et al (2000). (-)-Spiro[1azabicyclo[2.2.2] octane-3,5'-oxazolidin-2'-one], a conformationally restricted analogue of acetylcholine, is a highly selective full agonist at the alpha 7 nicotinic acetylcholine receptor. J Med Chem 43: 4045-4050.

Nanri M, Kasahara N, Yamamoto J, Miyake H, Watanabe H (1998). A comparative study on the effects of nicotine and GTS-21, a new nicotinic agonist, on the locomotor activity and brain monoamine level. Jpn J Pharmacol 78: 385-389.

Natesan S, Reckless GE, Barlow KB, Nobrega JN, Kapur S (2007). Evaluation of $\mathrm{N}$-desmethylclozapine as a potential antipsychotic_-preclinical studies. Neuropsychopharmacology 32: 1540-1549.

Nawaratne V, Leach K, Felder CC, Sexton PM, Christopoulos A (2010). Structural determinants of allosteric agonism and modulation at the M4 muscarinic acetylcholine receptor: identification of ligand-specific and global activation mechanisms. J Biol Chem 285: 19012-19021. 
Newhouse PA, Potter A, Corwin J, Lenox R (1992). Acute nicotinic blockade produces cognitive impairment in normal humans. Psychopharmacology 108: 480-484.

Newhouse PA, Potter A, Corwin J, Lenox R (1994). Age-related effects of the nicotinic antagonist mecamylamine on cognition and behavior. Neuropsychopharmacology 10: 93-107.

Newhouse PA, Potter A, Singh A (2004). Effects of nicotinic stimulation on cognitive performance. Curr Opin Pharmacol 4: 36-46.

$\mathrm{Ng}$ HJ, Whittemore ER, Tran MB, Hogenkamp DJ, Broide RS, Johnstone TB et al (2007). Nootropic alpha7 nicotinic receptor allosteric modulator derived from GABAA receptor modulators. Proc Natl Acad Sci USA 104: 8059-8064.

Nuechterlein KH, Barch DM, Gold JM, Goldberg TE, Green MF, Heaton RK (2004). Identification of separable cognitive factors in schizophrenia. Schizophr Res 72: 29-39.

Obinu MC, Reibaud M, Miquet JM, Pasquet M, Rooney T (2002). Brain-selective stimulation of nicotinic receptors by TC-1734 enhances ACh transmission from frontoparietal cortex and memory in rodents. Prog Neuropsychopharmacol Biol Psychiatry 26: 913-918.

Olincy A, Harris JG, Johnson LL, Pender V, Kongs S, Allensworth D et al (2006). Proof-of-concept trial of an alpha nicotinic agonist in schizophrenia. Arch Gen Psychiatry 63: 630-638.

Orr-Urtreger A, Göldner FM, Saeki M, Lorenzo I, Goldberg L, De Biasi M et al (1997). Mice deficient in the alpha7 neuronal nicotinic acetylcholine receptor lack alphabungarotoxin binding sites and hippocampal fast nicotinic currents. J Neurosci 17: 9165-9171.

Osterholm RK, Camoriano JK (1982). Transdermal scopolamine psychosis. JAMA 247: 3081.

Palma E, Bertrand S, Binzoni T, Bertrand D (1996). Neuronal nicotinic alpha 7 receptor expressed in Xenopus oocytes presents five putative binding sites for methyllycaconitine. J Physiol 491: 151-161.

Parsons B, Allison DB, Loebel A, Williams K, Giller E, Romano S et al (2009). Weight effects associated with antipsychotics: a comprehensive database analysis. Schizophr Res 110: 103-110.

Paylor R, Nguyen M, Crawley JN, Patrick J, Beaudet A, Orr-Urtreger A (1998). Alpha7 nicotinic receptor subunits are not necessary for hippocampaldependent learning or sensorimotor gating: a behavioral characterization of Acra7-deficient mice. Learn Membr 5: 302-316.

Pazzagli A, Pepeu G (1965). Amnesic properties of scopolamine and brain acetylcholine in the rat. Int $J$ Neuropharmacol 4: 291-299.

Perry DC, Xiao Y, Nguyen HN, Musachio JL, Dávila-García MI, Kellar KJ (2002). Measuring nicotinic receptors with characteristics of alpha4beta2, alpha3beta2 and alpha3beta4 subtypes in rat tissues by autoradiography. $J$ Neurochem $\mathbf{8 2}$ : 468-481.

Perry KW, Nisenbaum LK, George CA, Shannon HE, Felder CC, Bymaster FP (2001). The muscarinic agonist xanomeline increases monoamine release and immediate early gene expression in the rat prefrontal cortex. Biol Psychiatry 49: $716-725$.

Pfeiffer CC, Jenny EH (1957). The inhibition of the conditioned response and the counteraction of schizophrenia by muscarinic stimulation of the brain. Ann NY Acad Sci 66: 753-764.

Phelps PE, Houser CR, Vaughn JE (1985). Immunocytochemical localization of choline acetyltransferase within the rat neostriatum: a correlated light and electron microscopic study of cholinergic neurons and synapses. J Comp Neurol 238: 286-307.

Picciotto MR, Addy NA, Mineur YS, Brunzell DH (2008). It is not 'either/or': activation and desensitization of nicotinic acetylcholine receptors both contribute to behaviors related to nicotine addiction and mood. Prog Neurobiol 84: 329-342.

Pichat P, Bergis OE, Terranova JP, Urani A, Duarte C, Santucci V et al (2007). SSR180711, a novel selective alpha7 nicotinic receptor partial agonist: (II) efficacy in experimental models predictive of activity against cognitive symptoms of schizophrenia. Neuropsychopharmacology 32: 17-34.

Poulin B, Butcher A, McWilliams P, Bourgognon JM, Pawlak R, Kong KC et al (2010). The M3-muscarinic receptor regulates learning and memory in a receptor phosphorylation/arrestin-dependent manner. Proc Natl Acad Sci USA 107: 9440-9445.

Powchik P, Davidson M, Haroutunian V, Gabriel SM, Purohit DP, Perl DP et al (1998). Postmortem studies in schizophrenia. Schizophr Bull 24: 325-341.

Prendergast MA, Jackson WJ, Terry Jr AV, Decker MW, Arneric SP, Buccafusco JJ (1998). Central nicotinic receptor agonists ABT-418, ABT-089, and (-)-nicotine reduce distractibility in adult monkeys. Psychopharmacology 136: 50-58.

Prendergast MA, Terry Jr AV, Jackson WJ, Marsh KC, Decker MW, Arneric SP et al (1997). Improvement in accuracy of delayed recall in aged and non-aged, mature monkeys after intramuscular or transdermal administration of the CNS nicotinic receptor agonist ABT-418. Psychopharmacology 130: 276-284.
Quirion R, Richard J, Wilson A (1994). Muscarinic and nicotinic modulation of cortical acetylcholine release monitored by in vivo microdialysis in freely moving adult rats. Synapse 17: 92-100.

Rabin RA, Sacco KA, George TP (2009). Correlation of prepulse inhibition and Wisconsin Card Sorting Test in schizophrenia and controls: effects of smoking status. Schizophr Res 114: 91-97.

Radek RJ, Kohlhaas KL, Rueter LE, Mohler EG (2010). Treating the cognitive deficits of schizophrenia with alpha4beta2 neuronal nicotinic receptor agonists. Curr Pharm Des 16: 309-322.

Raedler TJ, Knable MB, Jones DW, Urbina RA, Gorey JG, Lee KS et al (2003). In vivo determination of muscarinic acetylcholine receptor availability in schizophrenia. Am J Psychiatry 160: 118-127.

Raedler TJ, Schreiner A, Naber D, Wiedemann K (2007). Early onset of treatment effects with oral risperidone. BMC Psychiatry 7: 4.

Redrobe JP, Nielsen EØ, Christensen JK, Peters D, Timmermann DB, Olsen GM (2009). Alpha7 nicotinic acetylcholine receptor activation ameliorates scopolamine-induced behavioural changes in a modified continuous $Y$-maze task in mice. Eur J Pharmacol 602: 58-65.

Rezvani AH, Kholdebarin E, Brucato FH, Callahan PM, Lowe DA, Levin ED (2009). Effect of R3487/MEM3454, a novel nicotinic alpha7 receptor partial agonist and 5-HT3 antagonist on sustained attention in rats. Prog Neuropsychopharmacol Biol Psychiatry 33: 269-275.

Rezvani AH, Levin ED (2001). Cognitive effects of nicotine. Biol Psychiatry 49: 258-267.

Roncarati R, Scali C, Comery TA, Grauer SM, Aschmi S, Bothmann H et al (2009). Procognitive and neuroprotective activity of a novel alpha7 nicotinic acetylcholine receptor agonist for treatment of neurodegenerative and cognitive disorders. $J$ Pharmacol Exp Ther 329: 459-468.

Ropert N, Krnjević K (1982). Pharmacological characteristics of facilitation of hippocampal population spikes by cholinomimetics. Neuroscience 7: 1963-1977.

Rouse ST, Edmunds SM, Yi H, Gilmor ML, Levey Al (2000). Localization of M(2) muscarinic acetylcholine receptor protein in cholinergic and non-cholinergic terminals in rat hippocampus. Neurosci Lett 284: 182-186.

Rouse ST, Gilmor ML, Levey Al (1998). Differential presynaptic and postsynaptic expression of $\mathrm{ml}-\mathrm{m} 4$ muscarinic acetylcholine receptors at the perforant pathway/granule cell synapse. Neuroscience 86: 221-232.

Rouse ST, Marino MJ, Potter LT, Conn PJ, Levey Al (1999). Muscarinic receptor subtypes involved in hippocampal circuits. Life Sci 64: 501-509.

Rupniak NM, Steventon MJ, Field MJ, Jennings CA, Iversen SD (1989). Comparison of the effects of four cholinomimetic agents on cognition in primates following disruption by scopolamine or by lists of objects. Psychopharmacology 99: 189-195.

Rusted JM, Warburton DM (1988). The effects of scopolamine on working memory in healthy young volunteers. Psychopharmacology 96: 145-152.

Sacco KA, Termine A, Dudas MM, Seyal AA, Allen TM, Vessicchio JC et al (2006). Neuropsychological deficits in nonsmokers with schizophrenia: effects of a nicotinic antagonist. Schizophr Res 85: 213-221.

Sacco KA, Termine A, Seyal A, Dudas MM, Vessicchio JC, Krishnan-Sarin S et al (2005). Effects of cigarette smoking on spatial working memory and attentional deficits in schizophrenia: involvement of nicotinic receptor mechanisms. Arch Gen Psychiatry 62: 649-659.

Sarter M, Parikh V, Howe WM (2009). nAChR agonist-induced cognition enhancement: integration of cognitive and neuronal mechanisms. Biochem Pharmacol 78 658-667.

Satoh K, Fibiger HC (1986). Cholinergic neurons of the laterodorsal tegmental nucleus: efferent and afferent connections. J Comp Neurol 253: 277-302.

Scarr E, Cowie TF, Kanellakis S, Sundram S, Pantelis C, Dean B (2009). Decreased cortical muscarinic receptors define a subgroup of subjects with schizophrenia. Mol Psychiatry 14: 1017-1023.

Schoepfer R, Conroy WG, Whiting P, Gore M, Lindstrom J (1990). Brain alphabungarotoxin binding protein cDNAs and MAbs reveal subtypes of this branch of the ligand-gated ion channel gene superfamily. Neuron 5: 35-48.

Seeger T, Fedorova I, Zheng F, Miyakawa T, Koustova E, Gomeza J et al (2004). M2 muscarinic acetylcholine receptor knock-out mice show deficits in behavioral flexibility, working memory, and hippocampal plasticity. I Neurosci 24: !QJ;10117-10127.

Seguela P, Wadiche J, Dineley-Miller K, Dani JA, Patrick JW (1993). Molecular cloning, functional properties, and distribution of rat brain alpha 7: a nicotinic cation channel highly permeable to calcium. J Neurosci 13: 596-604.

Severance EG, Yolken RH (2008). Novel alpha7 nicotinic receptor isoforms and deficient cholinergic transcription in schizophrenia. Genes Brain Behav 7: 37-45.

Shannon HE, Rasmussen K, Bymaster FP, Hart JC, Peters SC, Swedberg MD et al (2000). Xanomeline, an $M(1) / M(4)$ preferring muscarinic cholinergic receptor agonist, produces antipsychotic-like activity in rats and mice. Schizophr Res 42: 249-259. 
Shekhar A, Potter WZ, Lightfoot J, Lienemann J, Dubé S, Mallinckrodt C et al (2008). Selective muscarinic receptor agonist xanomeline as a novel treatment approach for schizophrenia. Am J Psychiatry 165: 1033-1039.

Sher E, Chen Y, Sharples TJ, Broad LM, Benedetti G, Zwart R et al (2004). Physiological roles of neuronal nicotinic receptor subtypes: new insights on the nicotinic modulation of neurotransmitter release, synaptic transmission and plasticity. Curr Top Med Chem 4: 283-297.

Shirey JK, Brady AE, Jones PJ, Davis AA, Bridges TM, Kennedy JP et al (2009). A selective allosteric potentiator of the M1 muscarinic acetylcholine receptor increases activity of medial prefrontal cortical neurons and restores impairments in reversal learning. J Neurosci 29: 14271-14286.

Shirey JK, Xiang Z, Orton D, Brady AE, Johnson KA, Williams R et al (2008). An allosteric potentiator of M4 mAChR modulates hippocampal synaptic transmission. Nat Chem Biol 4: 42-50.

Simosky JK, Stevens KE, Kem WR, Freedman R (2001). Intragastric DMXB-A, an alpha7 nicotinic agonist, improves deficient sensory inhibition in DBA/2 mice. Biol Psychiatry 50: 493-500.

Siok CJ, Rogers JA, Kocsis B, Hajos M (2006). Activation of alpha7 acetylcholine receptors augments stimulation-induced hippocampal theta oscillation. Eur $J$ Neurosci 23: 570-574.

Smith RC, Lindenmayer JP, Davis JM, Cornwell J, Noth K, Gupta S et al (2009). Cognitive and antismoking effects of varenicline in patients with schizophrenia or schizoaffective disorder. Schizophr Res 110: 149-155.

Smith RC, Warner-Cohen J, Matute M, Butler E, Kelly E, Vaidhyanathaswamy S et al (2006). Effects of nicotine nasal spray on cognitive function in schizophrenia. Neuropsychopharmacology 31: 637-643.

Söderman A, Mikkelsen JD, West MJ, Christensen DZ, Jensen MS (2011). Activation of nicotinic $\alpha(7)$ acetylcholine receptor enhances long term potentation in wild type mice but not in APP(swe)/PS1 $\Delta$ E9 mice. Neurosci Lett 487: 325-329.

Soliakov L, Gallagher T, Wonnacott S (1995). Anatoxin-a-evoked [3H]dopamine release from rat striatal synaptosomes. Neuropharmacology 34: 1535-1541.

Soliakov L, Wonnacott S (1996). Voltage-sensitive Ca2+ channels involved in nicotinic receptor-mediated $[3 \mathrm{H}]$ dopamine release from rat striatal synaptosomes. J Neurochem 67: 163-170.

Sood A, Beach JW, Webster SJ, Terry Jr AV, Buccafusco JJ (2007). The effects of JWB 1-84-1 on memory-related task performance by amyloid $A \beta$ transgenic mice and aged Rhesus monkeys. Neuropharmacology 53: 588-600.

Spalding TA, Trotter C, Skjaerbaek N, Messier TL, Currier EA, Burstein ES et al (2002). Discovery of an ectopic activation site on the $M(I)$ muscarinic receptor. Mol Pharmacol 61: 1297-1302.

Spencer JP, Middleton LJ, Davies CH (2010). Investigation into the efficacy of the acetylcholinesterase inhibitor, donepezil, and novel procognitive agents to induce gamma oscillations in rat hippocampal slices. Neuropharmacology 59: $437-443$.

Stanhope KJ, Mirza NR, Bickerdike MJ, Bright JL, Harrington NR, Hesselink MB et al (2001). The muscarinic receptor agonist xanomeline has an antipsychoticlike profile in the rat. J Pharmacol Exp Ther 299: 782-792.

Stassen HH, Bridler R, Hägele S, Hergersberg M, Mehmann B, Schinzel A et al (2000). Schizophrenia and smoking: evidence for a common neurobiological basis? Am J Med Genet 96: 173-177.

Stefansson H, Rujescu D, Cichon S, Pietiläinen OP, Ingason A, Steinberg S et al (2008). Large recurrent microdeletions associated with schizophrenia. Nature 455: 232-236.

Stevens KE, Freedman R, Collins AC, Hall M, Leonard S, Marks MJ et al (1996). Genetic correlation of inhibitory gating of hippocampal auditory evoked response and alpha-bungarotoxin-binding nicotinic cholinergic receptors in inbred mouse strains. Neuropsychopharmacology 15: 152-162.

Stevens KE, Kem WR, Mahnir VM, Freedman R (1998). Selective alpha7-nicotinic agonists normalize inhibition of auditory response in DBA mice. Psychopharmacology 136: 320-327.

Stevens KE, Wear KD (1997). Normalizing effects of nicotine and a novel nicotinic agonist on hippocampal auditory gating in two animal models. Pharmacol Biochem Behav 57: 869-874.

Stevens KE, Cornejo B, Adams CE, Zheng L, Yonchek J, Hoffman KL et al (2010). Continuous administration of a selective alpha7 nicotinic partial agonist, DMXBA, improves sensory inhibition without causing tachyphylaxis or receptor upregulation in DBA/2 mice. Brain Res 1352: 140-146.

Steidl S, Yeomans JS (2009). M5 muscarinic receptor knockout mice show reduced morphine-induced locomotion but increased locomotion after cholinergic antagonism in the ventral tegmental area. J Pharmacol Exp Ther 328: 263-275.

Sur C, Mallorga PJ, Wittmann M, Jacobson MA, Pascarella D, Williams JB et al (2003). N-desmethylclozapine, an allosteric agonist at muscarinic 1 receptor, potentiates N-methyl-D-aspartate receptor activity. Proc Natl Acad Sci USA 100: 13674-13679.
Swartz MS, Stroup TS, McEvoy JP, Davis SM, Rosenheck RA, Keefe RS et al (2008). What CATIE found: results from the schizophrenia trial. Psychiatry Serv 59: 500-506.

Sydserff S, Sutton EJ, Song D, Quirk MC, Maciag C, Li C et al (2009). Selective alpha7 nicotinic receptor activation by AZD0328 enhances cortical dopamine release and improves learning and attentional processes. Biochem Pharmacol 78: 880-888.

Tandon R, Shipley JE, Greden JF, Mann NA, Eisner WH, Goodson J (1991). Muscarinic cholinergic hyperactivity in schizophrenia. Relationship to positive and negative symptoms. Schizophr Res 4: 23-30.

Tapia L, Kuryatov A, Lindstrom J (2007). Ca2+ permeability of the (alpha4)3(beta2)2 stoichiometry greatly exceeds that of (alpha4)2(beta2)3 human acetylcholine receptors. Mol Pharmacol 71: 769-776.

Terry Jr AV, Buccafusco JJ, Jackson WJ, Zagrodnik S, Evans-Martin FF, Decker MW (1996). Effects of stimulation or blockade of central nicotinic-cholinergic receptors on performance of a novel version of the rat stimulus discrimination task. Psychopharmacology 123: 172-181.

Terry Jr AV, Buccafusco JJ, Prendergast MA (1999). Dose-specific improvements in memory-related task performance by rats and aged monkeys administered the nicotinic-cholinergic antagonist mecamylamine. Drug Dev Res 47: 127-136.

Thomsen M, Woldbye DP, Woertwein G, Fink-Jensen A, Wess J, Caine SB (2005). Reduced cocaine self-administration in muscarinic M5 acetylcholine receptordeficient mice. Neuropsychopharmacology 30: S88-S88.

Thomsen M, Wörtwein G, Fink-Jensen A, Woldbye DP, Wess J, Caine SB (2007). Decreased prepulse inhibition and increased sensitivity to muscarinic, but not dopaminergic drugs in M5 muscarinic acetylcholine receptor knockout mice. Psychopharmacology (Berl) 192: 97-110.

Thomsen MS, Christensen DZ, Hansen HH, Redrobe JP, Mikkelsen JD (2009). Alpha(7) nicotinic acetylcholine receptor activation prevents behavioral and molecular changes induced by repeated phencyclidine treatment. Neuropharmacology 56: 1001-1009.

Thomsen MS, Hay-Schmidt A, Hansen HH, Mikkelsen JD (2010). Distinct neural pathways mediate $\alpha 7$ nicotinic acetylcholine receptor-dependent activation of the forebrain. Cereb Cortex 20: 2092-2102.

Timmermann DB, Grønlien JH, Kohlhaas KL, Nielsen EØ, Dam E, Jørgensen TD et al (2007). An allosteric modulator of the alpha7 nicotinic acetylcholine receptor possessing cognition-enhancing properties in vivo. J Pharmacol Exp Ther 323: 294-307.

Tregellas JR, Olincy A, Johnson L, Tanabe J, Shatti S, Martin LF et al (2010). Functional magnetic resonance imaging of effects of a nicotinic agonist in schizophrenia. Neuropsychopharmacology 35: 938-942.

Tregellas JR, Tanabe J, Rojas DC, Shatti S, Olincy A, Johnson L et al (2011). Effects of an alpha 7-nicotinic agonist on default network activity in schizophrenia. Biol Psychiatry 69: 7-11.

Tsai G, Coyle JT (2002). Glutamatergic mechanisms in schizophrenia. Annu Rev Pharmacol Toxicol 42: 165-179.

Tzavara ET, Bymaster FP, Davis RJ, Wade MR, Perry KW, Wess J et al (2004). M4 muscarinic receptors regulate the dynamics of cholinergic and dopaminergic neurotransmission: relevance to the pathophysiology and treatment of related CNS pathologies. FASEB J 18: 1410-1412.

Tzavara ET, Bymaster FP, Felder CC, Wade M, Gomeza J, Wess J et al (2003). Dysregulated hippocampal acetylcholine neurotransmission and impaired cognition in M2, M4 and M2/M4 muscarinic receptor knockout mice. Mol Psychiatry 8: 673-679.

Van Kampen M, Selbach K, Schneider R, Schiegel E, Boess F, Schreiber R (2004). AR-R 17779 improves social recognition in rats by activation of nicotinic alpha7 receptors. Psychopharmacology 172: 375-383.

Vanover KE, Veinbergs I, Davis RE (2008). Antipsychotic-like behavioral effects and cognitive enhancement by a potent and selective muscarinic M-sub-1 receptor agonist, AC-260584. Behav Neurosci 122: 570-575.

Vicens P, Ribes D, Torrente M, Domingo JL. (2011). Behavioral effects of PNU-282987, an alpha7 nicotinic receptor agonist, in mic. Behav Brain Res 216: $341-348$

Vilaro MT, Palacios JM, Mengod G (1990). Localization of m5 muscarinic receptor mRNA in rat brain examined by in situ hybridization histochemistry. Neurosci Lett 114: $154-159$

Waldo MC, Woodward L, Adler LE (2010). Varenicline and P50 auditory gating in medicated schizophrenic patients: a pilot study. Psychiatry Res 175: 179-180.

Wallace TL, Callahan PM, Tehim A, Bertrand D, Tombaugh G, Wang S et al (2011). RG3487, a novel nicotinic $\alpha 7$ receptor partial agonist, improves cognition and sensorimotor gating in rodents. J Pharmacol Exp Ther 336: 242-253.

Weiner DM, Levey Al, Brann MR (1990). Expression of muscarinic acetylcholine and dopamine receptor mRNAs in rat basal ganglia. Proc Natl Acad Sci USA 87: 7050-7054. 
Wess J, Eglen RM, Gautam D (2007). Muscarinic acetylcholine receptors: mutant mice provide new insights for drug development. Nat Rev Drug Discov 6: 721-733.

Wildeboer KM, Stevens KE (2008). Stimulation of the alpha4beta2 nicotinic receptor by 5-I A-85380 improves auditory gating in DBA/2 mice. Brain Res 1224: 29-36. Wishka DG, Walker DP, Yates KM, Reitz SC, Jia S, Myers JK et al (2006). Discovery of $\mathrm{N}$-[(3R)-1-azabicyclo[2.2.2]oct-3-yl]furo[2,3-c]pyridine-5-carboxamide, an agonist of the alpha7 nicotinic acetylcholine receptor, for the potential treatment of cognitive deficits in schizophrenia: synthesis and structure - activity relationship. J Med Chem 49: 4425-4436.

Wonnacott S (1997). Presynaptic nicotinic ACh receptors. Trends Neurosci 20 92-98.

Wonnacott S, Kaiser S, Mogg A, Soliakov L, Jones IW (2000). Presynaptic nicotinic receptors modulating dopamine release in the rat striatum. Eur J Pharmaco/ 393: 51-58.

Woznica AA, Sacco KA, George TP (2009). Prepulse inhibition deficits in schizophrenia are modified by smoking status. Schizophr Res 112: 86-90.

Xiao Y, Fan H, Musachio JL, Wei ZL, Chellappan SK, Kozikowski AP et al (2006). Sazetidine-A, a novel ligand that desensitizes $\alpha 4 \beta 2$ nicotinic acetylcholine receptors without activating them. Mol Pharmacol 70: 1454-1460.

Yamada M, Basile AS, Fedorova I, Zhang W, Duttaroy A, Cui Y et al (2003). Novel insights into M5 muscarinic acetylcholine receptor function by the use of gene targeting technology. Life Sci 74: 345-353.
Yamada M, Lamping KG, Duttaroy A, Zhang W, Cui Y, Bymaster FP et al (2001a). Cholinergic dilation of cerebral blood vessels is abolished in M5 muscarinic acetylcholine receptor knockout mice. Proc Natl Acad Sci USA 98 14096-14101.

Yamada M, Miyakawa T, Duttaroy A, Yamanaka A, Moriguchi T, Makita R et al (2001b). Mice lacking the M3 muscarinic acetylcholine receptor are hypophagic and lean. Nature 410: 207-212.

Young CD, Meltzer HY, Deutch AY (1998). Effects of desmethylclozapine on Fos protein expression in the forebrain: in vivo biological activity of the clozapine metabolite. Neuropsychopharmacology 19: 99-103.

Zang Z, Creese I (1997). Differential regulation of expression of rat hippocampal muscarinic receptor subtypes following fimbria-fornix lesion. Biochem Pharmacol 53: 1379-1382.

Zhang W, Basile AS, Gomeza J, Volpicelli LA, Levey Al, Wess J (2002). Characterization of central inhibitory muscarinic autoreceptors by the use of muscarinic acetylcholine receptor knockout mice. J Neurosci 22: 1709-1717.

Zavitsanou K, Katsifis A, Mattner F, Huang XF (2004). Investigation of m1/m4 muscarinic receptors in the anterior cingulate cortex in schizophrenia, bipolar disorder, and major depression disorder. Neuropsychopharmacology 29: 619-625.

Zoli M, Picciotto MR, Ferrari R, Cocchi D, Changeux JP (1999). Increased neurodegeneration during ageing in mice lacking high-affinity nicotine receptors. EMBO J 18: 1235-1244. 